Cover. Photograph shows Rush Brook in autumn. 


\section{Streamflow, Water Quality, and Constituent Loads and Yields, Scituate Reservoir Drainage Area, Rhode Island, Water Year 2006}

By Robert F. Breault and Jean P. Campbell

Prepared in cooperation with the

Providence Water Supply Board and the

Rhode Island Department of Environmental Management

Open-File Report 2010-1046 


\section{U.S. Department of the Interior \\ KEN SALAZAR, Secretary \\ U.S. Geological Survey \\ Marcia K. McNutt, Director}

U.S. Geological Survey, Reston, Virginia: 2010

For more information on the USGS - the Federal source for science about the Earth, its natural and living resources, natural hazards, and the environment, visit http://www.usgs.gov or call 1-888-ASK-USGS

For an overview of USGS information products, including maps, imagery, and publications, visit http://www.usgs.gov/pubprod

To order this and other USGS information products, visit http://store.usgs.gov

Any use of trade, product, or firm names is for descriptive purposes only and does not imply endorsement by the U.S. Government.

Although this report is in the public domain, permission must be secured from the individual copyright owners to reproduce any copyrighted materials contained within this report.

Suggested citation:

Breault, R.F., and Campbell, J.P., 2010, Streamflow, water quality, and constituent loads and yields, Scituate Reservoir drainage area, Rhode Island, water year 2006: U.S. Geological Survey Open-File Report 2010-1046, 25 p.

(Also available at http://pubs.usgs.gov/of/2010/1046.) 


\section{Contents}

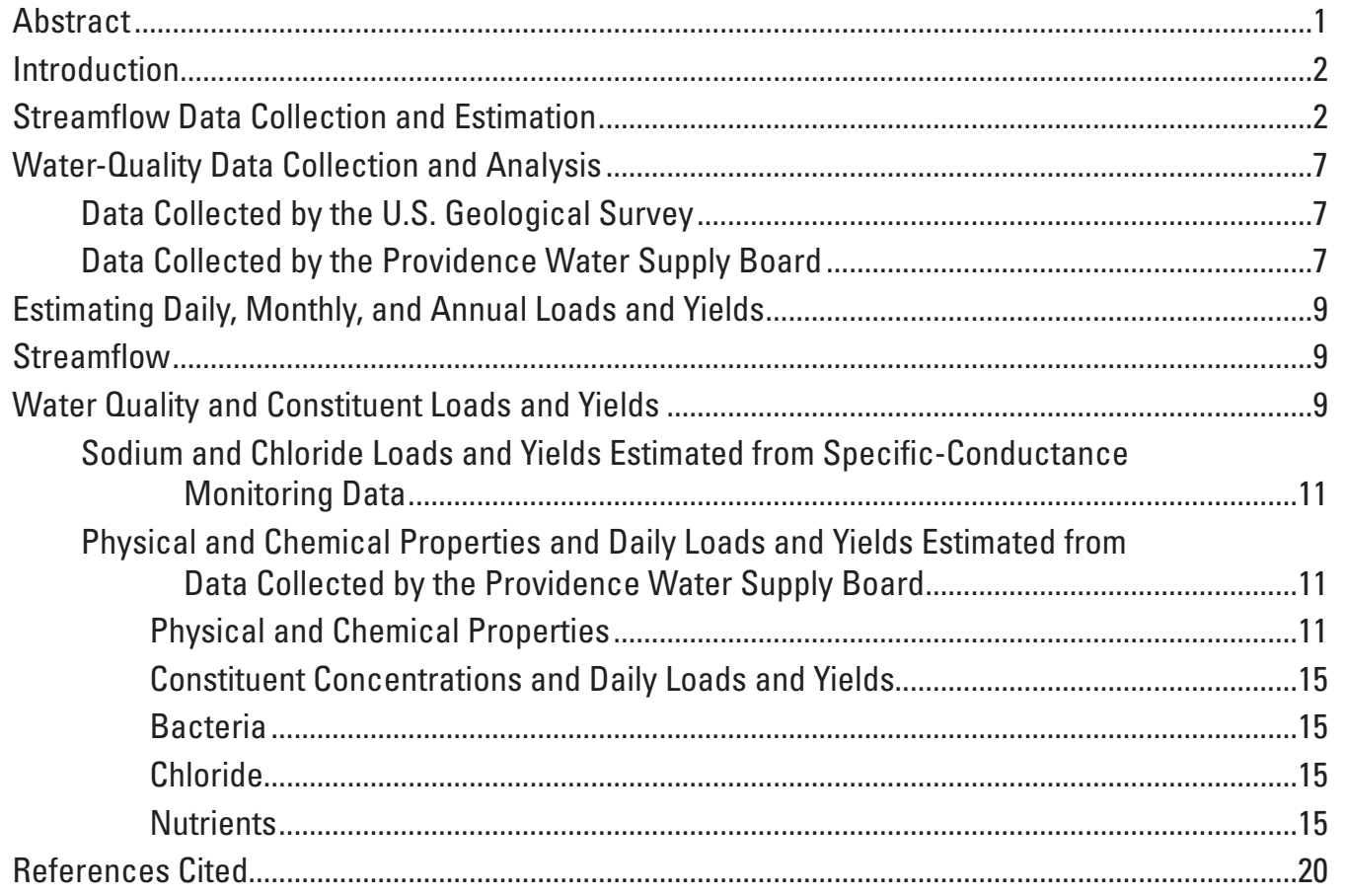

\section{Figures}

1. Map showing locations of tributary-reservoir subbasins and streamgage and water-quality monitoring stations in the Scituate Reservoir drainage area, Rhode Island

2. Graph showing flow-duration curve for the U.S. Geological Survey continuous streamgage station on Ponaganset River at South Foster (station 01115187) for water year 2006 and streamflow measurements at the Ponaganset River gaging station on the dates when water-quality samples were collected at Dolly Cole Brook.

3. Graph showing measured daily mean streamflow for the U.S. Geological Survey continuous-record gaging station on the Ponaganset River at South Foster (station 01115187) in the Scituate Reservoir drainage area, Rhode Island, for October 1, 2005, through September 30, 2006, and mean daily streamflow for March 22, 1994, through July 13, 2008. 


\section{Tables}

1. Providence Water Supply Board water-quality sampling stations, water-quality samples, and available streamflow and continuous monitoring stations by tributary reservoir subbasin, in the Scituate Reservoir drainage area, Rhode Island, October 1, 2005, to September 30, 2006.

2. Measured or estimated annual mean streamflow for tributary streams in the Scituate Reservoir drainage area, Rhode Island, October 1, 2005, through September 30, 2006.

3. Daily loads of bacteria, chloride, nitrite, nitrate, and orthophosphate by tributary reservoir subbasin in the Scituate Reservoir drainage area, Rhode Island, October 1, 2005, through September 30, 2006

4. Monthly mean concentrations of chloride and sodium estimated from continuous measurements of specific conductance in the Scituate Reservoir drainage area, Rhode Island, October 1, 2005, through September 30, 2006.

5. Annual mean chloride and sodium concentrations, loads, and yields by sampling station in the Scituate Reservoir drainage area, Rhode Island, October 1, 2005, through September 30, 2006

6. Monthly estimated chloride and sodium loads by sampling station in the Scituate Reservoir drainage area, Rhode Island, October 1, 2005, through September 30, 2006.

7. Median values for water-quality data collected at Providence Water stations, by tributary reservoir subbasin, in the Scituate Reservoir drainage area, Rhode Island, October 1, 2005, through September 30, 2006

8. Median daily loads and yields of bacteria, chloride, nitrite, nitrate, and orthophosphate by tributary reservoir subbasin in the Scituate Reservoir drainage area, Rhode Island, October 1, 2005, through September 30, 2006

\section{Conversion Factors}

\begin{tabular}{lcl}
\hline \multicolumn{1}{c}{ Multiply } & By & \multicolumn{1}{c}{ To obtain } \\
\hline & Area & \\
\hline square mile $\left(\mathrm{mi}^{2}\right)$ & 2.590 & square kilometer $\left(\mathrm{km}^{2}\right)$ \\
\hline & Flow rate & \\
\hline cubic foot per second $\left(\mathrm{ft}^{3} / \mathrm{s}\right)$ & 0.02832 & cubic meter per second $\left(\mathrm{m}^{3} / \mathrm{s}\right)$ \\
\hline & Mass & \\
\hline ton, short $(2,000 \mathrm{lb})$ & 907.2 & kilogram $(\mathrm{kg})$ \\
ton, short $(2,000 \mathrm{lb})$ & 907,200 & gram $(\mathrm{kg})$ \\
\hline
\end{tabular}

Concentrations of chemical constituents in water are given either in milligrams per liter (mg/L) or colony forming units per 100 milliliters (CFU/100 mL).

Loads of chemical constituents in water are given either in grams or kilograms (or millions of colony forming units for bacteria) per day, month, or year and yields in grams or kilograms (or millions of colony forming units for bacteria) per day, month, or year per square mile. 


\title{
Streamflow, Water Quality, and Constituent Loads and Yields, Scituate Reservoir Drainage Area, Rhode Island, Water Year 2006
}

\author{
By Robert F. Breault and Jean P. Campbell
}

\begin{abstract}
Streamflow and water-quality data were collected by the U.S. Geological Survey (USGS) or the Providence Water Supply Board, Rhode Island's largest drinking-water supplier. Streamflow was measured or estimated by the USGS following standard methods at 23 streamgage stations; 10 of these stations were also equipped with instrumentation capable of continuously monitoring specific conductance. Streamflow and concentrations of sodium and chloride estimated from records of specific conductance were used to calculate instantaneous (15-minute) loads of sodium and chloride during water year (WY) 2006 (October 1, 2005, to September 30, 2006). Water-quality samples were also collected at 37 sampling stations in the Scituate Reservoir drainage area by the Providence Water Supply Board during WY 2006 as part of a long-term sampling program. Water-quality data are summarized by using values of central tendency and are used, in combination with measured (or estimated) streamflows, to calculate loads and yields (loads per unit area) of selected water-quality constituents for WY 2006.

The largest tributary to the reservoir (the Ponaganset River, which was monitored by the USGS) contributed about 42 cubic feet per second $\left(\mathrm{ft}^{3} / \mathrm{s}\right)$ to the reservoir during WY 2006. For the same time period, annual mean streamflows ${ }^{1}$ measured (or estimated) for the other monitoring stations in this study ranged from about 0.60 to $26 \mathrm{ft}^{3} / \mathrm{s}$. Together, tributary streams (equipped with instrumentation capable of continuously monitoring specific conductance) transported about 1,600,000 kilograms ( $\mathrm{kg}$ ) of sodium and 2,500,000 kg of chloride to the Scituate Reservoir during WY 2006; sodium and chloride yields for the tributaries ranged from 15,000 to 100,000 kilograms per square mile $\left(\mathrm{kg} / \mathrm{mi}^{2}\right)$ and from 22,000 to $180,000 \mathrm{~kg} / \mathrm{mi}^{2}$, respectively.

At the stations where water-quality samples were collected by the Providence Water Supply Board, the median of the median chloride concentrations was 24.6 milligrams per liter $(\mathrm{mg} / \mathrm{L})$, median nitrite concentration was $0.001 \mathrm{mg} / \mathrm{L}$ as $\mathrm{N}$, median nitrate concentration was $0.02 \mathrm{mg} / \mathrm{L}$ as $\mathrm{N}$, median orthophosphate concentration was $0.07 \mathrm{mg} / \mathrm{L}$ as $\mathrm{P}$, and median concentrations of total coliform and Escherichia coli (E. coli) bacteria were 43 and 23 colony forming units per 100 milliliters $(\mathrm{CFU} / 100 \mathrm{~mL})$, respectively. The medians of the median daily loads (and yields) of chloride, nitrite, nitrate, orthophosphate, and total coliform and E. coli bacteria were $230 \mathrm{~kg} / \mathrm{d}\left(81 \mathrm{~kg} / \mathrm{d} / \mathrm{mi}^{2}\right), 17 \mathrm{~g} / \mathrm{d}\left(4.4 \mathrm{~g} / \mathrm{d} / \mathrm{mi}^{2}\right), 130 \mathrm{~g} / \mathrm{d}\left(50 \mathrm{~g} / \mathrm{d} / \mathrm{mi}^{2}\right)$, $470 \mathrm{~g} / \mathrm{d}\left(210 \mathrm{~g} / \mathrm{d} / \mathrm{mi}^{2}\right)$, and 2,100 million colony forming units per day (CFU $\left.\times 10^{6} / \mathrm{d}\right)$ $\left(1,300 \mathrm{CFU} \times 10^{6} / \mathrm{d} / \mathrm{mi}^{2}\right)$ and $670 \mathrm{CFU} \times 10^{6} / \mathrm{d}\left(420 \mathrm{CFU} \times 106 / \mathrm{d} / \mathrm{mi}^{2}\right)$, respectively.
\end{abstract}

The arithmetic mean of the individual daily mean discharges for the year noted or for the designated period. 


\section{Introduction}

The Scituate Reservoir is the primary source of drinking water for more than 60 percent of the population of Rhode Island. It covers about $94 \mathrm{mi}^{2}$ in parts of the towns of Cranston, Foster, Glocester, Johnston, and Scituate, R.I.

(fig. 1). Information about the water quality of the reservoir and its tributary streams is important for management of the water supply and for the protection of human health. The Providence Water Supply Board (Providence Water), the agency responsible for the management and distribution of the Scituate Reservoir water supply, has been monitoring and assessing water quality in the reservoir and reservoir drainage area for more than 50 years.

Since 1993, the U.S. Geological Survey (USGS) has been cooperating with Providence Water and the Rhode Island Department of Environmental Management (RIDEM) to measure streamflow in tributaries to the Scituate Reservoir. Streamflow has been continuously measured at 2 streamgage stations in the drainage area and has been periodically measured at 21 additional stations on tributaries in the drainage area. At these 21 partial-record stations, continuous streamflow records have been estimated by using methods developed by the USGS (Hirsch, 1982). More recently (since 2000), the USGS also has been continuously measuring specific conductance at 10 monitoring stations. Equations that relate specific conductance to concentrations of sodium and chloride in streamwater also were developed as part of a previous USGS/Providence Water cooperative study (Nimiroski and Waldron, 2002). These equations, updated here and used together with measured (or estimated) streamflows, allow for nearly continuous estimation of sodium and chloride loads to the reservoir (Nimiroski and Waldron, 2002).

Currently (2009), Providence Water regularly collects water-quality samples from 37 tributary streams, either monthly or quarterly. Occasionally, samples are collected from other streams or stations as needed. Water-quality results are summarized by monitoring station and constituent or parameter in annual reports published by Providence Water. In addition, over the past 10 years, USGS reports have compiled and tabulated streamflow (measured or estimated by USGS) and water-quality data (collected by Providence Water; Breault and others, 2000; Nimiroski and others, 2008).

This report presents data on streamflow, water quality, and loads and yields of selected constituents for water year ${ }^{2}$ (WY) 2006 in the Scituate Reservoir drainage area. These data were collected as part of studies done by the USGS in cooperation with Providence Water and the RIDEM. A summary of measured and estimated streamflows is presented for the 2 continuous-record and 21 partial-record streamgage stations in the drainage area. Estimated monthly loads and annual loads (and yields) of sodium and chloride are presented for the 10 stations at which specific conductance is continuously monitored by the USGS. Summary statistics

\footnotetext{
${ }^{2}$ October 1, 2005, to September 30, 2006.
}

for water-quality data collected by Providence Water at 37 sampling stations during WY 2006 also are presented, and these data were used to calculate loads and yields of selected water-quality constituents (table 1).

\section{Streamflow Data Collection and Estimation}

Streamflow and water-quality data were collected by the USGS or Providence Water. Streamflow was measured or estimated by the USGS at 23 streamgage stations. Measured and estimated streamflows are necessary to estimate water volume and water-quality constituent loads and yields from tributary basins. At continuous-record streamgage stations, stream stage is measured every 15 minutes. Streamflow is computed with a stage-discharge relation (or rating), which is developed on the basis of periodic manual measurements. Daily mean streamflow at a station is calculated by dividing the total volume of water that passes the station each day by 86,400 , the number of seconds in a day. Periodic manual streamflow measurements at partial-record gaging stations are used with concurrent continuous-record measurements from stations in hydrologically similar drainage areas to estimate a continuous record at the partial-record site. Specifically, continuous streamflow records for the 21 partial-record sites in the Scituate Reservoir drainage area were estimated by using the Maintenance of Variance Extension type 1 (MOVE.1) method, as described by Ries and Friesz (2000); data needed to estimate streamflows at partial-record sites were retrieved from the USGS National Water Inventory System (NWIS; http://waterdata.usgs.gov/nwis/) and formatted. Streamflows were estimated by MOVE.1 method by using a suite of USGS-developed computer programs (Granato, 2008). Errors for estimated streamflows are expressed as the upper and lower 90-percent confidence limits, as described by Tasker and Driver (1988) (table 2); there is a 90-percent chance that streamflow is somewhere between the upper and lower 90-percent confidence limits.

Continuous-record streamgage stations were operated and maintained by the USGS during WY 2006 on Peeptoad Brook (USGS station number 01115098 and Providence Water station number 16, in cooperation with RIDEM) and on the Ponaganset River (USGS station number 01115187 and Providence Water station number 35, in cooperation with Providence Water; fig. 1 and table 1). Streamflow data for these two gaging stations were collected at 15-minute intervals (near-real-time streamflow data), were updated at 2-hour intervals on the World Wide Web (WWW), and are available through the NWIS Web Interface (NWIS Web; U.S. Geological Survey, 2006). Error associated with measured streamflows in Peeptoad Brook and Ponaganset River was generally within about 15 percent (U.S. Geological Survey, 2007); upper and lower 90-percent confidence limits calculated by methods described by the National Institute of 

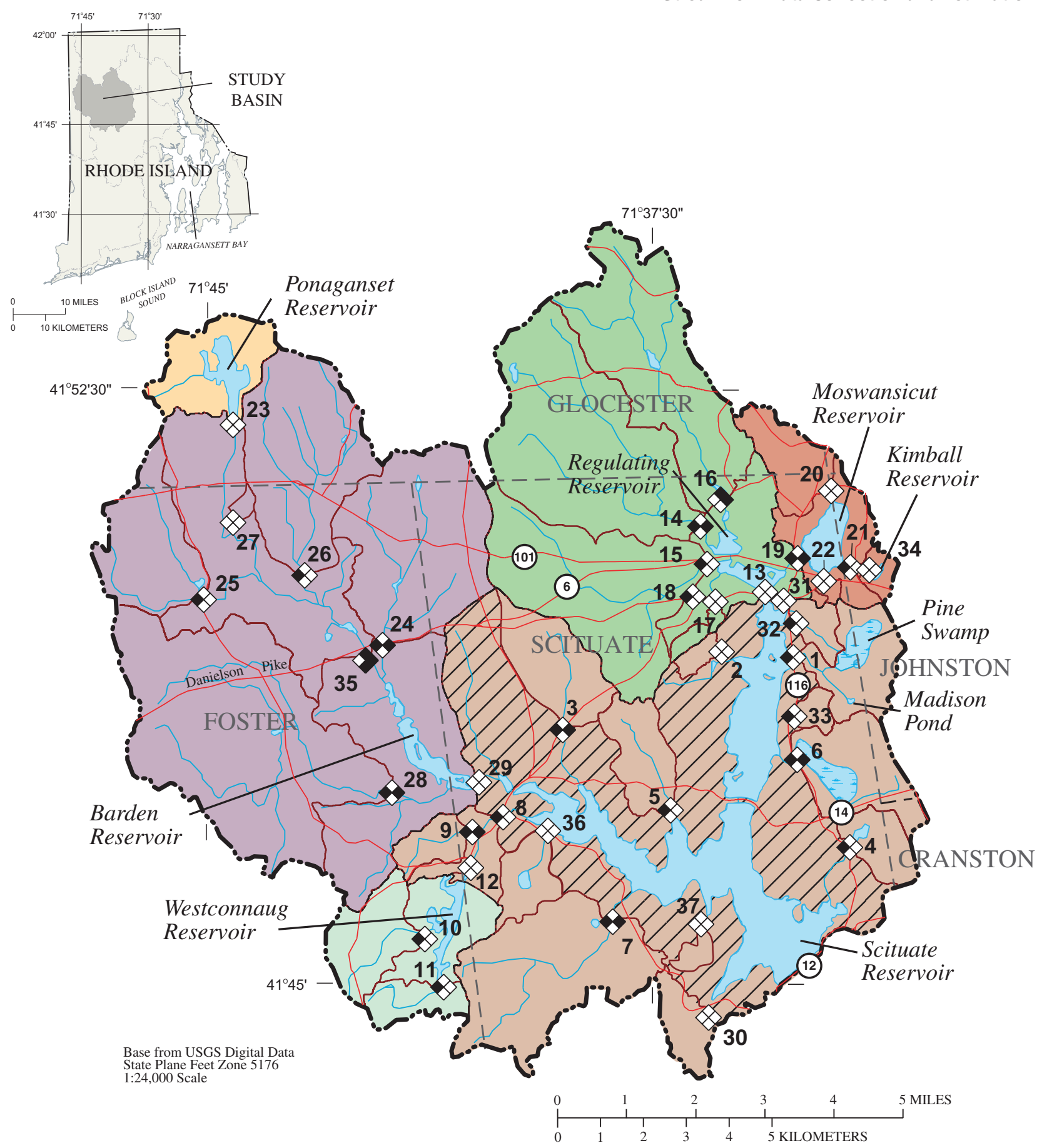

EXPLANATION

Subbasins and reservoir areas

Barden Reservoir subbasins

Direct Runoff subbasins

Moswansicut Reservoir subbasins

Ponaganset Reservoir subbasins

Regulating Reservoir subbasins

Westconnaug Reservoir subbasins

Unsampled area draining directly to Scituate Reservoir
Streamflow or water-quality monitoring station and identifier-black squares indicate measurements made by U.S. Geological Survey
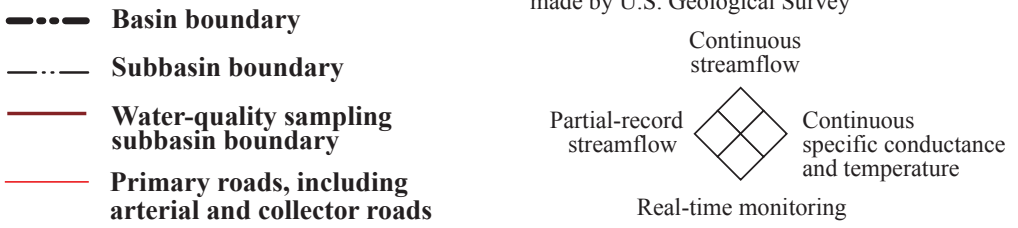

Real-time monitoring

Figure 1. Locations of tributary-reservoir subbasins and streamgage and water-quality monitoring stations in the Scituate Reservoir drainage area, Rhode Island. 
Table 1. Providence Water Supply Board water-quality sampling stations, water-quality samples, and available streamflow and continuous monitoring stations by tributary reservoir subbasin, in the Scituate Reservoir drainage area, Rhode Island, October 1, 2005, to September 30, 2006.

[PW, Providence Water; USGS, U.S. Geological Survey; no., number; mi², square miles; QW, water quality; M, monthly; Q, quarterly; Y, yes; N, no; $\mathrm{Na}$, sodium; $\mathrm{Cl}$, chloride; --, none; Alternate station names given for stations where different historical names were used for the same sampling location by Providence Water.]

\begin{tabular}{|c|c|c|c|c|c|c|c|c|}
\hline $\begin{array}{l}\text { PW } \\
\text { station } \\
\text { no. }\end{array}$ & $\begin{array}{l}\text { USGS } \\
\text { station } \\
\text { no. }\end{array}$ & Station name & $\begin{array}{l}\text { Drainage } \\
\text { area } \\
\left(\mathrm{mi}^{2}\right)\end{array}$ & $\begin{array}{c}\text { Station } \\
\text { active } \\
\text { during } \\
\text { study } \\
\text { period }\end{array}$ & $\begin{array}{c}\text { Frequency } \\
\text { of } \mathrm{OW} \\
\text { sample } \\
\text { collection }\end{array}$ & $\begin{array}{l}\text { Number of } \\
\text { samples } \\
\text { collected by } \\
\text { Providence } \\
\text { Water }^{1} \\
\end{array}$ & $\begin{array}{c}\text { Daily } \\
\text { estimated } \\
\text { Na and Cl } \\
\text { loads }\end{array}$ & $\begin{array}{l}\text { Estimated } \\
\text { streamflow } \\
\text { calculated }\end{array}$ \\
\hline \multicolumn{9}{|c|}{ Barden Reservior subbasin } \\
\hline 24 & 01115190 & Dolly Cole Brook & 4.90 & $\mathrm{Y}$ & M & 11 & $\mathrm{Y}$ & $\mathrm{Y}$ \\
\hline 27 & 011151845 & $\begin{array}{l}\text { Unnamed Tributary to Ponaganset } \\
\text { River (Unnamed Brook B, Unnamed } \\
\text { Brook West of Windsor Brook) }\end{array}$ & 0.10 & Y & Q & 3 & $\mathrm{~N}$ & $\mathrm{~N}$ \\
\hline 28 & 01115265 & Barden Reservoir (Hemlock Brook) & 8.72 & $\mathrm{Y}$ & M & 12 & $\mathrm{Y}$ & $\mathrm{Y}$ \\
\hline 29 & 01115271 & Ponaganset River (Barden Stream) & 33.0 & $\mathrm{Y}$ & M & 11 & $\mathrm{~N}$ & $\mathrm{~N}$ \\
\hline \multicolumn{9}{|c|}{ Direct Runoff subbasin } \\
\hline 1 & 01115180 & Brandy Brook & 1.57 & $\mathrm{Y}$ & M & 12 & $\mathrm{~N}$ & $\mathrm{Y}$ \\
\hline 2 & 01115181 & $\begin{array}{l}\text { Unnamed Tributary \#2 to Scituate } \\
\text { Reservoir (Unnamed Brook North of } \\
\text { Bullhead Brook) }\end{array}$ & 0.15 & $\mathrm{Y}$ & Q & 3 & $\mathrm{~N}$ & $\mathrm{~N}$ \\
\hline 3 & 01115280 & Cork Brook & 1.79 & $\mathrm{Y}$ & M & 11 & $\mathrm{Y}$ & Y \\
\hline 4 & 01115400 & Kent Brook (Betty Pond Stream) & 0.85 & $\mathrm{Y}$ & M & 12 & $\mathrm{~N}$ & $\mathrm{Y}$ \\
\hline 5 & 01115184 & Spruce Brook & 1.22 & $\mathrm{Y}$ & $\mathrm{Q}$ & 4 & $\mathrm{~N}$ & Y \\
\hline 6 & 01115183 & Quonapaug Brook & 1.96 & $\mathrm{Y}$ & M & 10 & $\mathrm{Y}$ & $\mathrm{Y}$ \\
\hline 7 & 01115297 & Wilbur Hollow Brook & 4.32 & Y & M & 12 & $\mathrm{Y}$ & Y \\
\hline 8 & 01115276 & $\begin{array}{l}\text { Westconnaug Brook (Westconnaug } \\
\text { Reservoir) }\end{array}$ & 5.18 & Y & M & 10 & $\mathrm{~N}$ & Y \\
\hline 9 & 01115275 & Bear Tree Brook & 0.62 & $\mathrm{Y}$ & Q & 4 & $\mathrm{Y}$ & Y \\
\hline 30 & 01115350 & $\begin{array}{l}\text { Unnamed Tributary \#4 to Scituate } \\
\text { Reservoir (Coventry Brook, Knight } \\
\text { Brook) }\end{array}$ & 0.78 & $\mathrm{Y}$ & Q & 4 & $\mathrm{~N}$ & $\mathrm{~N}$ \\
\hline 31 & 01115177 & Toad Pond & 0.04 & Y & Q & 2 & $\mathrm{~N}$ & $\mathrm{~N}$ \\
\hline 32 & 01115178 & $\begin{array}{l}\text { Unnamed Tributary \#1 to Scituate } \\
\text { Reservoir (Pine Swamp Brook) }\end{array}$ & 0.45 & Y & Q & 4 & $\mathrm{~N}$ & $\mathrm{Y}$ \\
\hline 33 & 01115182 & $\begin{array}{l}\text { Unnamed Tributary \#3 to Scituate } \\
\text { Reservoir (Hall's Estate Brook) }\end{array}$ & 0.28 & $\mathrm{Y}$ & Q & 4 & $\mathrm{~N}$ & $\mathrm{Y}$ \\
\hline 36 & -- & Outflow from King Pond & 0.77 & $\mathrm{Y}$ & Q & 4 & $\mathrm{~N}$ & $\mathrm{~N}$ \\
\hline 37 & -- & Fire Tower Stream & 0.15 & $\mathrm{Y}$ & Q & 4 & $\mathrm{~N}$ & $\mathrm{~N}$ \\
\hline
\end{tabular}


Table 1. Providence Water Supply Board water-quality sampling stations, water-quality samples, and available streamflow and continuous monitoring stations by tributary reservoir subbasin, in the Scituate Reservoir drainage area, Rhode Island, 0ctober 1, 2005, to September 30, 2006. - Continued

[PW, Providence Water; USGS, U.S. Geological Survey; no., number; mi², square miles; QW, water quality; M, monthly; Q, quarterly; Y, yes; N, no; $\mathrm{Na}$, sodium; $\mathrm{Cl}$, chloride; --, none; Alternate station names given for stations where different historical names were used for the same sampling location by Providence Water.]

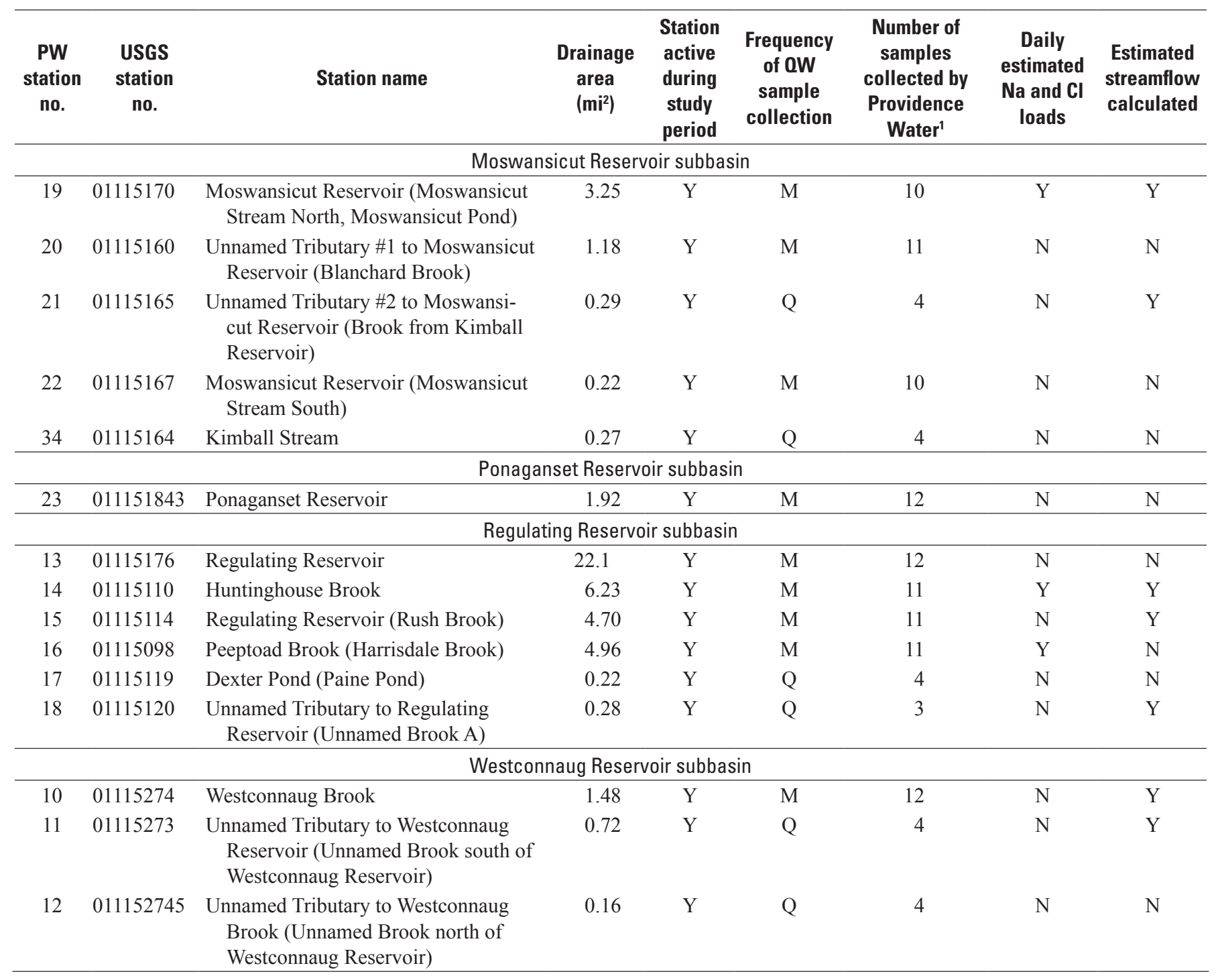

\footnotetext{
${ }^{1}$ Not all samples were analyzed for all water-quality properties or constituents.
} 
Table 2. Measured or estimated annual mean streamflow for tributary streams in the Scituate Reservoir drainage area, Rhode Island, October 1, 2005, through September 30, 2006.

[PW, Providence Water; USGS, U.S. Geological Survey; no., number; $\mathrm{ft}^{3} / \mathrm{s}$, cubic feet per second; $\mathrm{ft}^{3} / \mathrm{s} / \mathrm{mi}^{2}$, cubic feet per second per square mile]

\begin{tabular}{|c|c|c|c|c|c|c|}
\hline $\begin{array}{l}\text { PW } \\
\text { station } \\
\text { no. }\end{array}$ & $\begin{array}{l}\text { USGS } \\
\text { station } \\
\text { no. }\end{array}$ & Station name & $\begin{array}{c}\text { Annual mean } \\
\text { streamflow } \\
\left(\mathrm{ft}^{3} / \mathrm{s}\right)\end{array}$ & $\begin{array}{l}\text { Upper } 90 \text {-percent } \\
\text { confidence } \\
\text { interval } \\
\left(\mathrm{ft}^{3} / \mathrm{s}\right)\end{array}$ & $\begin{array}{l}\text { Lower 90-percent } \\
\text { confidence } \\
\text { interval } \\
\left(\mathrm{ft}^{3} / \mathrm{s}\right)\end{array}$ & $\begin{array}{c}\text { Normalized } \\
\text { annual mean } \\
\text { streamflow } \\
\left(\mathrm{ft}^{3} / \mathrm{mi}^{2}\right)\end{array}$ \\
\hline \multicolumn{7}{|c|}{ Barden Reservoir subbasin } \\
\hline 24 & 01115190 & Dolly Cole Brook & 15 & 54 & 4.2 & 3.1 \\
\hline 25 & 01115200 & Shippee Brook & 13 & 45 & 3.8 & 5.5 \\
\hline 26 & 01115185 & Windsor Brook & 14 & 50 & 3.8 & 3.2 \\
\hline 28 & 01115265 & Barden Reservoir (Hemlock Brook) & 26 & 68 & 10 & 3.0 \\
\hline 35 & 01115187 & Ponaganset River & 42 & 47 & 36 & 3.0 \\
\hline \multicolumn{7}{|c|}{ Direct Runoff subbasin } \\
\hline 1 & 01115180 & Brandy Brook & 3.9 & 9.2 & 1.7 & 2.5 \\
\hline 3 & 01115280 & Cork Brook & 5.4 & 13 & 2.3 & 3.0 \\
\hline 4 & 01115400 & Kent Brook (Betty Pond Stream) & 3.6 & 32 & 0.41 & 4.2 \\
\hline 5 & 01115184 & Spruce Brook & 4.9 & 20 & 1.2 & 4.0 \\
\hline 6 & 01115183 & Quonapaug Brook & 6.6 & 19 & 2.3 & 3.4 \\
\hline 7 & 01115297 & Wilbur Hollow Brook & 14 & 58 & 3.4 & 3.2 \\
\hline 8 & 01115276 & $\begin{array}{l}\text { Westconnaug Brook (Westconnaug } \\
\text { Reservoir) }\end{array}$ & 8.6 & 17 & 4.3 & 1.7 \\
\hline 9 & 01115275 & Bear Tree Brook & 1.7 & 3.1 & 0.89 & 2.7 \\
\hline 32 & 01115178 & $\begin{array}{l}\text { Unnamed Tributary \#1 to Scituate } \\
\text { Reservoir (Pine Swamp Brook) }\end{array}$ & 0.75 & 1.3 & 0.42 & 1.7 \\
\hline 33 & 01115182 & $\begin{array}{l}\text { Unnamed Tributary \#3 to Scituate } \\
\text { Reservoir (Hall's Estate Brook) }\end{array}$ & 1.4 & 3.7 & 0.54 & 5.0 \\
\hline \multicolumn{7}{|c|}{ Moswansicut Reservoir subbasin } \\
\hline 19 & 01115170 & $\begin{array}{l}\text { Moswansicut Reservoir (Moswansicut } \\
\text { Stream North, Moswansicut Pond) }\end{array}$ & 9.3 & 39 & 2.2 & 2.9 \\
\hline 21 & 01115165 & $\begin{array}{c}\text { Unnamed Tributary \#2 to Moswansi- } \\
\text { cut Reservoir (Blanchard Brook) }\end{array}$ & 0.90 & 3.9 & 0.21 & 3.1 \\
\hline \multicolumn{7}{|c|}{ Regulating Reservoir subbasin } \\
\hline 14 & 01115110 & Huntinghouse Brook & 21 & 66 & 6.4 & 3.3 \\
\hline 15 & 01115115 & Regulating Reservoir (Rush Brook) & 15 & 49 & 4.5 & 3.1 \\
\hline 16 & 01115098 & Peeptoad Brook (Harrisdale Brook) & 14 & 16 & 13 & 2.9 \\
\hline 18 & 01115120 & $\begin{array}{l}\text { Unnamed Tributary to Regulating } \\
\text { Reservoir }\end{array}$ & 0.60 & 1.5 & 0.24 & 2.1 \\
\hline \multicolumn{7}{|c|}{ Westconnaug Reservoir subbasin } \\
\hline 10 & 01115274 & Westconnaug Brook & 5.7 & 18 & 1.8 & 3.8 \\
\hline 11 & 01115273 & $\begin{array}{l}\text { Unnamed Tributary to Westconnaug } \\
\text { Reservoir (Unnamed Brook South } \\
\text { of Westconnaug Reservoir) }\end{array}$ & 5.8 & 19 & 1.8 & 8.1 \\
\hline
\end{tabular}




\section{Water-Quality Data Collection and Analysis}

Water-quality data were collected by the USGS or Providence Water. Concentrations of sodium and chloride were estimated (by USGS) from continuous records of specific conductance from 10 of the 23 streamgage stations. Waterquality samples were collected monthly or quarterly at 35 of 37 sampling stations in the Scituate Reservoir drainage area by Providence Water during WY 2002, as part of a long-term sampling program. Daily loads of chloride, bacteria, nitrate, nitrite, and orthophosphate were calculated at 23 monitoring stations where streamflow data were collected by USGS and water-quality samples were collected by Providence Water. Yields were calculated by dividing load by drainage area.

\section{Data Collected by the U.S. Geological Survey}

Water quality was monitored in a periodic water-quality sampling program that included measurements by automatic specific-conductance probes. The USGS collected and analyzed the specific conductance. Specific conductance was measured by the USGS at 15-minute intervals at the 10 monitoring stations, including the 2 continuous streamgage stations and 8 partial-record sites (fig. 1). Measurements were made by using an instream probe and standard USGS methods for continuous streamwater-quality monitoring (Wagner and others, 2006). Specific conductance data for the 10 monitoring stations were published in the USGS Annual Data Report for WY 2002 (Socolow and others, 2003).

Concentrations of sodium and chloride were estimated from continuous measurements of specific conductance by using equations that were developed by the USGS to relate specific conductance to concentrations of sodium and chloride (equations 1 and 2). These regression equations were developed by the MOVE.1 method (also known as the line of organic correlation; Helsel and Hirsch, 1992) on the basis of concurrent measurements of specific conductance along with sodium and chloride concentrations measured in water-quality samples collected from tributary streams in the Scituate Reservoir drainage area (Marcus Waldron, U.S. Geological Survey, written comm., 2008):

$$
\begin{gathered}
C_{N a}=\left(S p c^{1.1794}\right) \times 0.05240 \text { and } \\
C_{C l}=\left(S p c^{1.2828}\right) \times 0.05063,
\end{gathered}
$$

where

$$
\begin{gathered}
\mathrm{C}_{\mathrm{Na}} \quad \begin{array}{l}
\text { is the sodium concentration, in milligrams } \\
\text { per liter; }
\end{array} \\
\mathrm{C}_{\mathrm{Cl}} \quad \begin{array}{c}
\text { is the chloride concentration, in milligrams } \\
\text { per liter; and }
\end{array} \\
\mathrm{Spc} \quad \text { is the specific conductance, in microsiemens } \\
\text { per centimeter. }
\end{gathered}
$$

MOVE.1 was chosen for regression analysis to maintain variance (Hirsch and Gilroy, 1984). Some missing values of specific conductance were estimated. In these cases, seasonal (July to October; November to June) averages were used for estimated values of specific conductance.

\section{Data Collected by the Providence Water Supply Board}

Water-quality samples were collected at 35 of 37 monitoring stations by Providence Water. Sampling was monthly at 18 monitoring stations and quarterly at another 17 stations (table 1) during WY 2002. Water-quality samples were not collected during specific weather conditions; rather, a strictly periodic water-quality sampling schedule was followed so that water-quality samples would be representative of various weather conditions. However, sometimes samples could not be collected because streams at the sampling stations were dry or frozen. When possible, water-quality samples were collected by dipping the sample bottle into the stream at the center of flow (Richard Blodgett, Providence Water Supply Board, written commun., 2005). Samples were transported on ice to the water-quality laboratory of Providence Water at the P.J. Holton Water Purification Plant in Scituate, R.I. Water-quality properties and constituent concentrations were measured by using unfiltered water samples. These water-quality properties included $\mathrm{pH}$, temperature, acidity, alkalinity, color, turbidity, and concentrations of chloride, nitrite, nitrate, orthophosphate, and bacteria (Escherichia coli (E. coli) and total coliform). More information on sample-collection, analytical, and quality-control procedures can be found in the Providence Water Quality Assurance Program Manual (Providence Water Supply Board Water Quality Laboratory, 2003).

Providence Water collected samples during a wide range of flow conditions. The daily mean flow-duration curve for the Ponaganset River at South Foster (USGS station number 01115187) for WY2002 is shown in figure 2. The curve represents the percentage of time that each flow was exceeded at this station. The flows at this station on days when water-quality samples were collected at a representative station (Dolly Cole Brook, fig. 2) are represented by the plotted points superimposed on the curve. Samples were collected at flow durations ranging from the 1st percentile to the 90th percentile; this range indicates that water-quality samples collected in WY 2002 represent a wide range of flow conditions during that water year. 


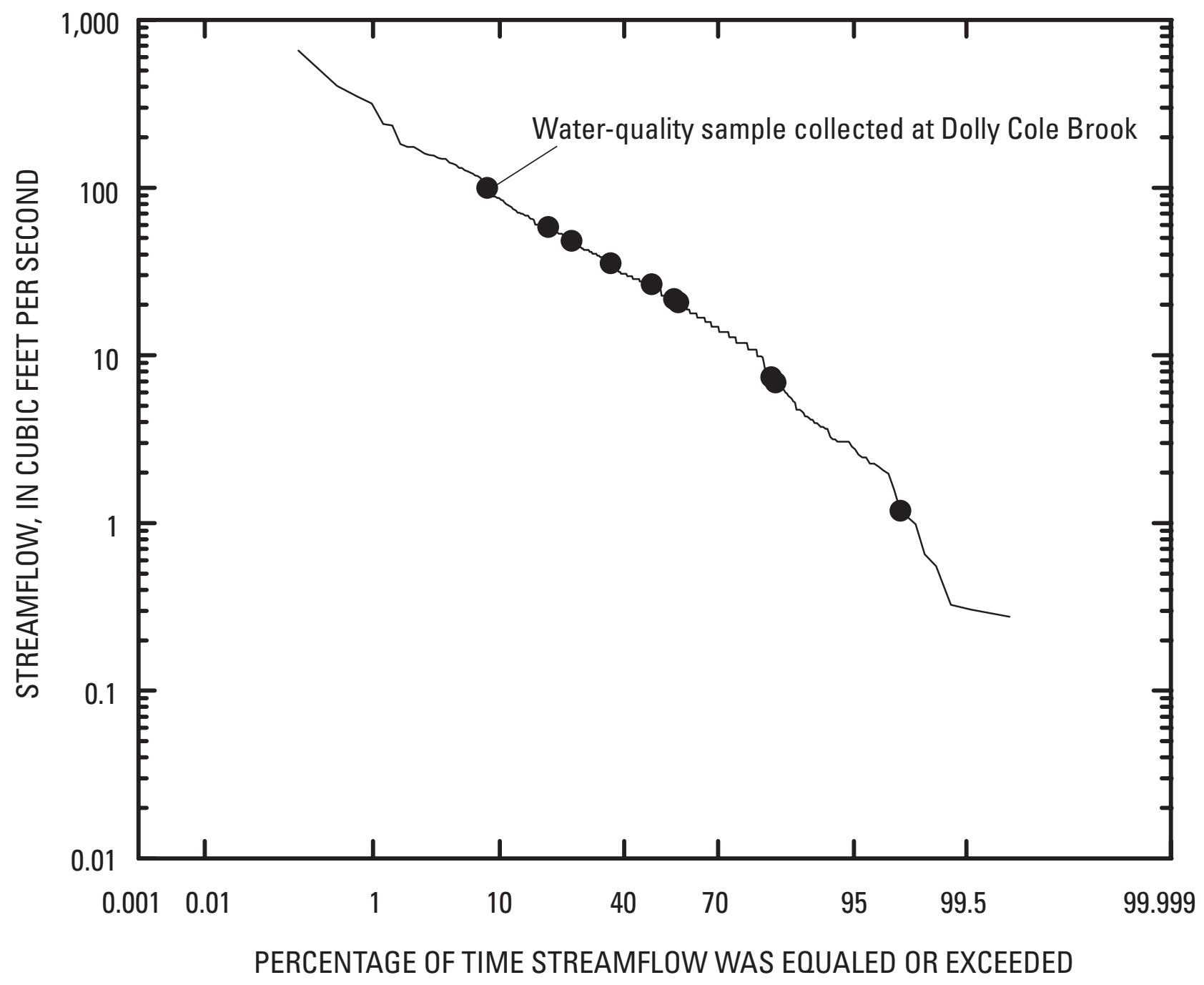

Figure 2. Flow-duration curve for the U.S. Geological Survey continuous streamgage station on Ponaganset River at South Foster (station 01115187) for water year 2006 and streamflow measurements at the Ponaganset River gaging station on the dates when water-quality samples were collected at Dolly Cole Brook (shown as points). 


\section{Estimating Daily, Monthly, and Annual Loads and Yields}

Daily, monthly, and annual sodium and chloride loads in kilograms were estimated for all sampling sites for which streamflow (periodic or continuous) and continuous specificconductance data were available during WY 2006. Daily sodium and chloride loads were estimated by multiplying daily (flow-weighted) concentrations of sodium and chloride in milligrams per liter by daily discharge (in liters per day) and added by month or water year. Daily flow-weighted concentrations of sodium and chloride were calculated by multiplying instantaneous flows by concurrent concentrations of sodium and chloride (estimated from measurements of specific conductance) for each day and dividing by the total flow for that day.

Daily loads of water-quality constituents (in samples collected by Providence Water) were calculated for all sampling dates during WY 2006 (table 3, at back of report) for which periodic or continuous streamflow data were available (table 1). These loads were calculated by multiplying constituent concentrations in milligrams per liter or colony forming units (CFU) per 100 milliliters in single samples multiplied by the daily discharge (in liters per day) for the day on which each sample was collected. The flows, which in most cases were estimates, were assumed to be representative of the flow at the time of the sample collection. Loads in grams or kilograms (or millions of CFUs for bacteria) per day and yields in grams or kilograms (or millions of CFUs for bacteria) per day per square mile were calculated for bacteria, chloride, nitrite, nitrate, and orthophosphate from this waterquality data. Censored data (or concentrations reported as less than method detection limits) were replaced with one-half the method detection limit.

\section{Streamflow}

Monitoring streamflow is necessary to measure the volume of water and estimate constituent loads to the Scituate Reservoir. The Ponaganset River is the largest monitored tributary to the Scituate Reservoir. Mean streamflow at the gaging station on the Ponaganset River (USGS station number 01115187) for the entire time period of its operation (mean of the daily mean streamflows for the period of record, WY 1994-2008) was $28 \mathrm{ft}^{3} / \mathrm{s}$ (http://waterdata.usgs.gov/ nwis). During WY 2006, annual mean streamflow was $42 \mathrm{ft}^{3} / \mathrm{s}$ (fig. 3; U.S. Geological Survey, 2007). Mean streamflow in Peeptoad Brook (01115098), the other continuous streamgage station in the Scituate Reservoir drainage area (USGS station number 01115098), for its period of record (WY 1994-2008) was $10 \mathrm{ft}^{3} / \mathrm{s}$ (http://waterdata.usgs.gov/nwis). Annual mean streamflow in Peeptoad Brook during WY 2006 was $14 \mathrm{ft}^{3} / \mathrm{s}$ (U.S. Geological Survey, 2007).

The 15-year periods of record at these two streamgage stations are shorter than time periods typically used to represent long-term average conditions. However, comparison with a nearby station having a period of record from WY 1940-2008 (Quinsigamond River at North Grafton, Mass., USGS station number 01110000) indicates that the distribution of streamflows regionally during the study period with respect to the long-term average flow at that station (42 $\mathrm{ft}^{3} / \mathrm{s}$; wdr.water.usgs.gov/) was similar to the distribution at Ponaganset River and Peeptoad Brook; the annual mean flow in WY 2006 was considerably higher than average $\left(67 \mathrm{ft}^{3} / \mathrm{s}\right.$; U.S. Geological Survey, 2007). Annual mean streamflows estimated for partial-record monitoring stations are given in table 2. Estimated annual mean streamflows at partial record stations ranged from 0.60 to $26 \mathrm{ft}^{3} / \mathrm{s}$. Annual mean streamflows normalized by drainage area ranged from 1.7 to $8.1 \mathrm{ft}^{3} / \mathrm{s} / \mathrm{mi}^{2}$ (table 2).

\section{Water Quality and Constituent Loads and Yields}

Water-quality conditions in the Scituate Reservoir drainage area are described by summary statistics for waterquality properties, constituent concentrations, and estimated constituent loads and yields. Loads and yields characterize the rates at which masses of constituents are transferred to the reservoir by tributary streams. In the case of loads, streams with higher flows tend to have higher loads because the greater volume of water carries more of the constituent to the reservoir per unit time. Yields represent the constituent load per unit of drainage area and are calculated by dividing the load estimated for a monitoring station by the drainage area to the station. Yields are useful for comparison among sites of different drainage-area sizes because the effects of basin size and therefore total streamflow volume are attenuated. Yields are useful for examining potential differences among basin properties that may contribute to reservoir quality.

Summary statistics include means and medians. For some purposes, median values are more appropriate because they are less likely to be affected by high or low concentrations (or outliers). Medians are especially important to use for summarizing a relatively limited number of values. In contrast, continuously monitored streamflow and sodium and chloride loads (estimated from measurements of specific conductance), which include a large number of values, are better summarized in terms of means because a large data set is more resistant to the effects of outliers. Mean values also are particularly appropriate for characterizing loads because outlier values, which typically represent large flows, are important to include when representing the delivery of constituent masses to receiving waters. 


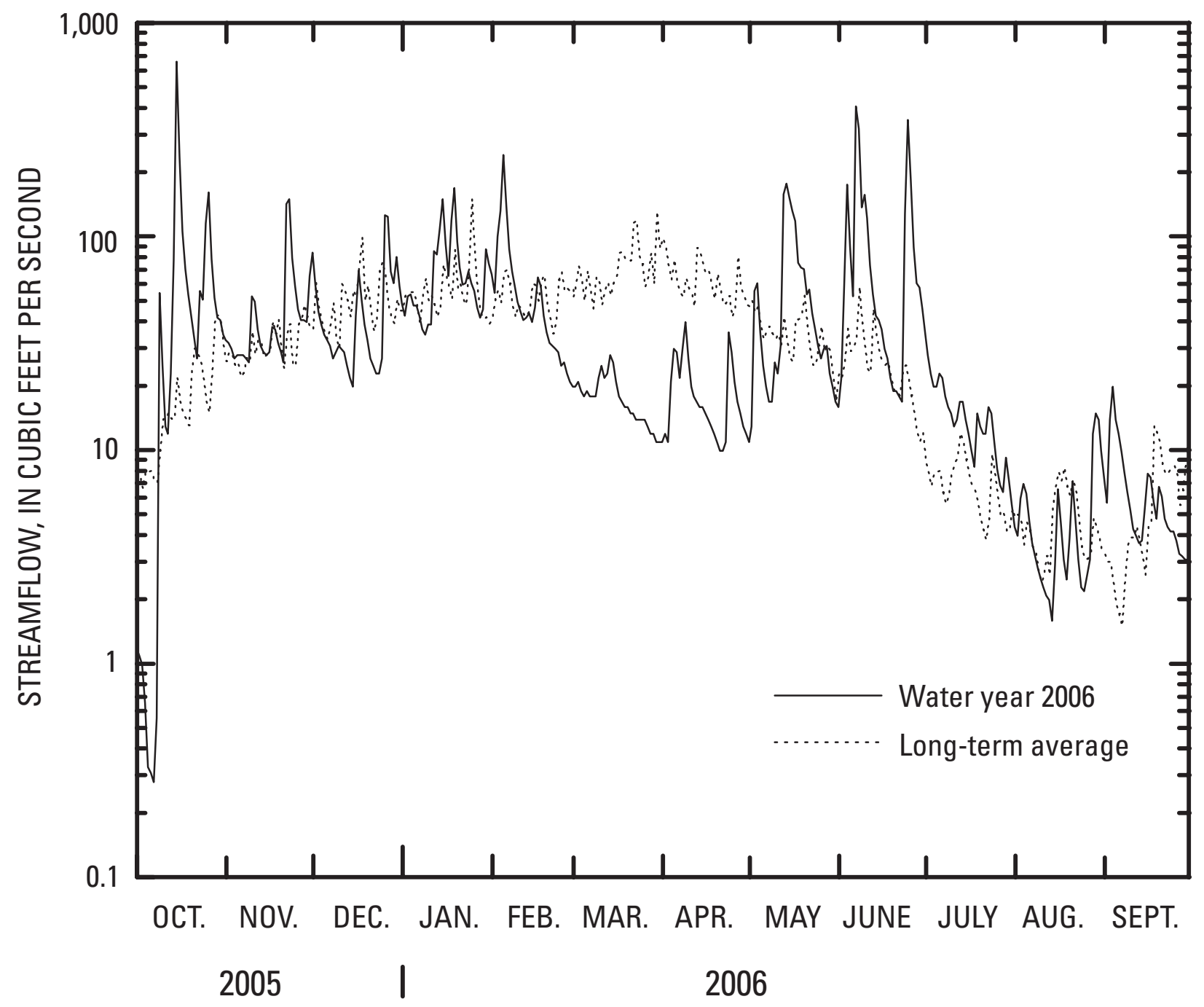

Figure 3. Measured daily mean streamflow for the U.S. Geological Survey continuous-record gaging station on the Ponaganset River at South Foster (station 01115187) in the Scituate Reservoir drainage area, Rhode Island, for October 1, 2005, through September 30, 2006 (solid line), and mean daily streamflow for March 22, 1994, through July 13, 2008 (dotted line). 


\section{Sodium and Chloride Loads and Yields Estimated from Specific-Conductance Monitoring Data}

Sodium and chloride are constituents of special concern in the Scituate Reservoir drainage area; they are major constituents of road salt used for deicing, and several major roadways cross the drainage basin. State Routes 12 and 14 cut across the main body of the reservoir, and State Route 116 parallels the eastern limb (fig. 1). A recent study by the USGS, in cooperation with Providence Water, indicates that tributary streams in basins with state-maintained roads have substantially higher concentrations of sodium and chloride, presumably because of deicing activities (Nimiroski and Waldron, 2002). In addition, sodium is a constituent of potential concern for human health; some persons on restrictive diets need to limit their intake of sodium.

Estimated monthly mean ${ }^{3}$ sodium concentrations in tributary streams of the Scituate Reservoir drainage area ranged from 4.0 to $73.2 \mathrm{mg} / \mathrm{L}$, and estimated monthly mean chloride concentrations ranged from 5.7 to $133 \mathrm{mg} / \mathrm{L}$. The highest monthly mean concentrations of sodium and chloride were measured at station 9 (Bear Tree Brook) in August 2006 (73.2 and $133 \mathrm{mg} / \mathrm{L}$, respectively) (table 4). The highest annual mean ${ }^{4}$ concentrations of sodium and chloride were measured at station 9 (Bear Tree Brook) at 42.8 and $74.6 \mathrm{mg} / \mathrm{L}$, respectively (table 5 ). These high values are not surprising because the waters that pass this station contain sodium and chloride from a formerly uncovered salt storage pile (Nimiroski and Waldron, 2002).

The Scituate Reservoir received about 1,600,000 kg (about 1,763 tons) of sodium and 2,500,000 kg (about 2,755 tons) of chloride from tributary streams - equipped with instrumentation capable of continuously monitoring specific conductance-during WY 2006. The highest sodium and chloride loads in WY 2006-330,000 and 500,000 kg, respectively - were measured at the Ponaganset River station (Providence Water Station Number 35) (table 5). Monthly sodium and chloride loads were highest in January (at four stations), June (three stations), October (two stations), and May (one station) (table 6). These sodium and chloride loads accounted for about $4,8,0.5$, and 4 percent of the annual load for each constituent, respectively. The highest annual sodium and chloride yields were 100,000 and $180,000 \mathrm{~kg} / \mathrm{mi}^{2}$,

\footnotetext{
${ }^{3}$ Monthly mean concentrations were calculated by dividing the total monthly load by the total discharge for the month.

${ }^{4}$ Annual mean concentrations were calculated by dividing the total annual load by the total discharge for the year.
}

respectively, and were measured at Bear Tree Brook (station 9; table 5).

Uncertainties associated with measuring streamflow and specific conductance and with sodium and chloride sample collection, preservation, and analysis produce uncertainties in load and yield estimates. The load and yield estimates presented in the text and tables are estimated to be the most likely values for loads and yields of sodium and chloride coming from tributary streams or their drainage basins. It may be best to discuss loads and yields in terms of a range within which the true values lie; however, the most probable values of loads and yields are presented for ease of discussion and presentation. The range within which the true values lie depends on the uncertainties in individual measurements of streamflow and concentration, which are difficult to quantify with available information. It is commonly assumed that the uncertainties associated with estimating streamflow affect load and yield calculations more than the error associated with measuring specific conductance and (or) chemical analysis. The most probable values of loads and yields presented in the tables and text are sufficient for planning-level analysis of water quality in tributary streams and their drainage basins.

\section{Physical and Chemical Properties and Daily Loads and Yields Estimated from Data Collected by the Providence Water Supply Board}

\section{Physical and Chemical Properties}

Physical and chemical properties including $\mathrm{pH}$, turbidity, alkalinity, specific conductance, and color were routinely measured to characterize water quality from each basin (table 7). Specifically, $\mathrm{pH}$ is a measure of the acidity of the water; color can be an indirect measure of the amount of organic carbon dissolved in the water column; turbidity is an indirect measure of suspended particles; and alkalinity is a measure of the acid-neutralizing capacity of water.

The median $\mathrm{pH}$ in tributary streams in the Scituate Reservoir drainage area ranged from 5.2 to 6.7; the median of the medians among all stations was 6.1. Median values of color ranged from 17 to 190 platinum cobalt units (PCU); the median among all stations was $40 \mathrm{PCU}$. Median values of turbidity ranged from 0.2 to 1.3 nephelometric turbidity units (NTU); the median among all stations was 0.4 NTU. Median alkalinity values in tributary streams were low, ranging from 2.2 to $13 \mathrm{mg} / \mathrm{L}$ as $\mathrm{CaCO}_{3}$; the median among all stations was $4.6 \mathrm{mg} / \mathrm{L}$ as $\mathrm{CaCO}_{3}$ (table 7). 
Table 4. Monthly mean concentrations of chloride and sodium estimated from continuous measurements of specific conductance in the Scituate Reservoir drainage area, Rhode Island, October 1, 2005, through September 30, 2006.

[PW, Providence Water; USGS, U.S. Geological Survey; no., number; mg/L, milligrams per liter; Cl, chloride; Na, sodium; the average root mean square error of the regression estimates for sodium and chloride are 1.2 and 0.06 , respectively; monthly mean concentrations were calculated by dividing the monthly load by the total discharge for the month]

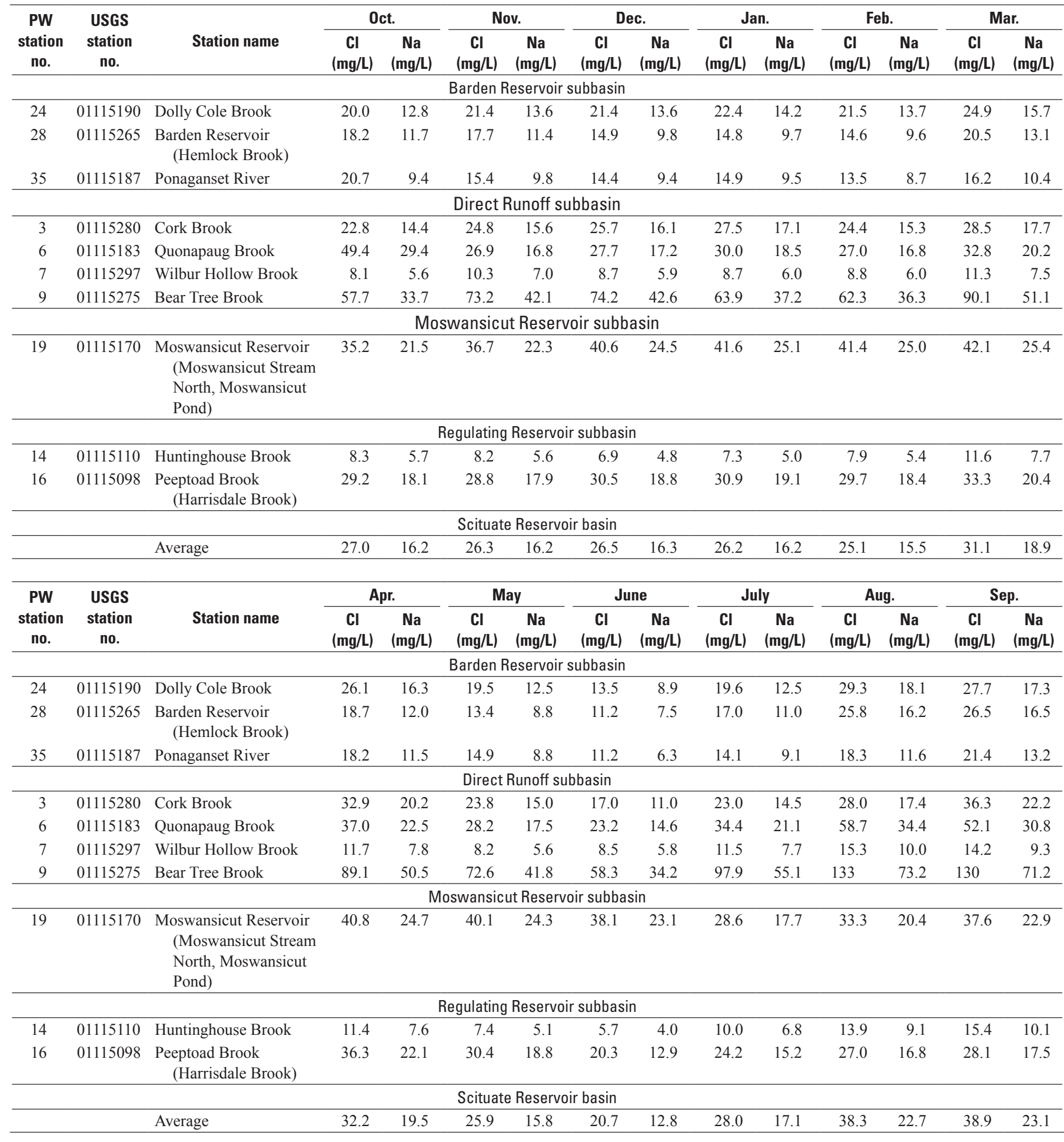


Table 5. Annual mean chloride and sodium concentrations, loads, and yields by sampling station in the Scituate Reservoir drainage area, Rhode Island, October 1, 2005, through September 30, 2006.

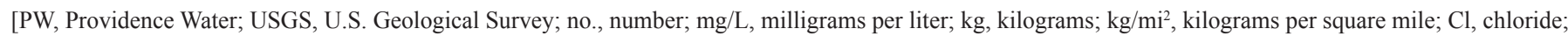
$\mathrm{Na}$, sodium; annual mean concentrations were calculated by dividing the annual load by the total discharge for the year.]

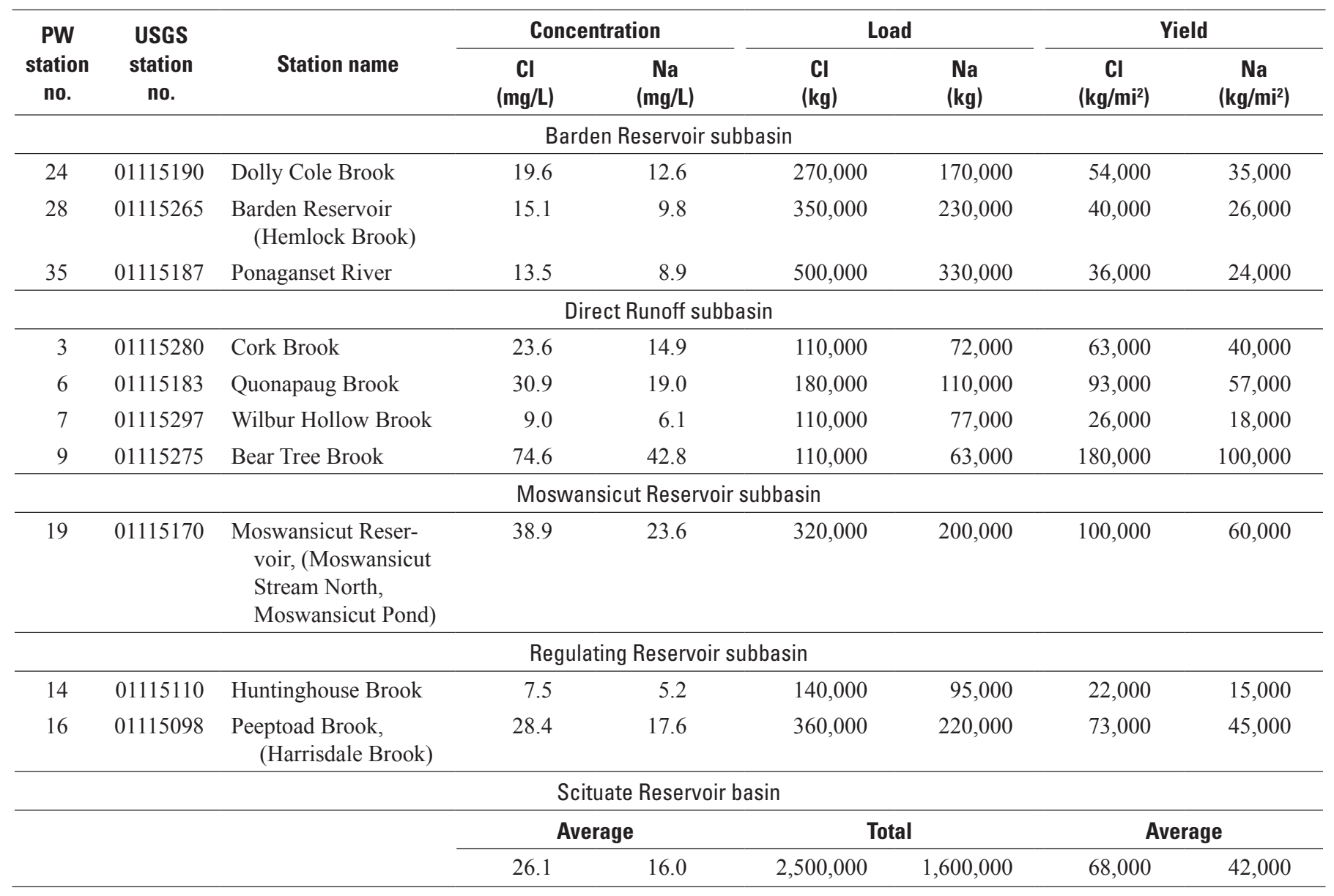


Table 6. Monthly estimated chloride and sodium loads by sampling station in the Scituate Reservoir drainage area, Rhode Island, October 1, 2005, through September 30, 2006.

[PW, Providence Water; USGS, U.S. Geological Survey; no., number; Cl, chloride; Na, sodium; kg, kilogram]

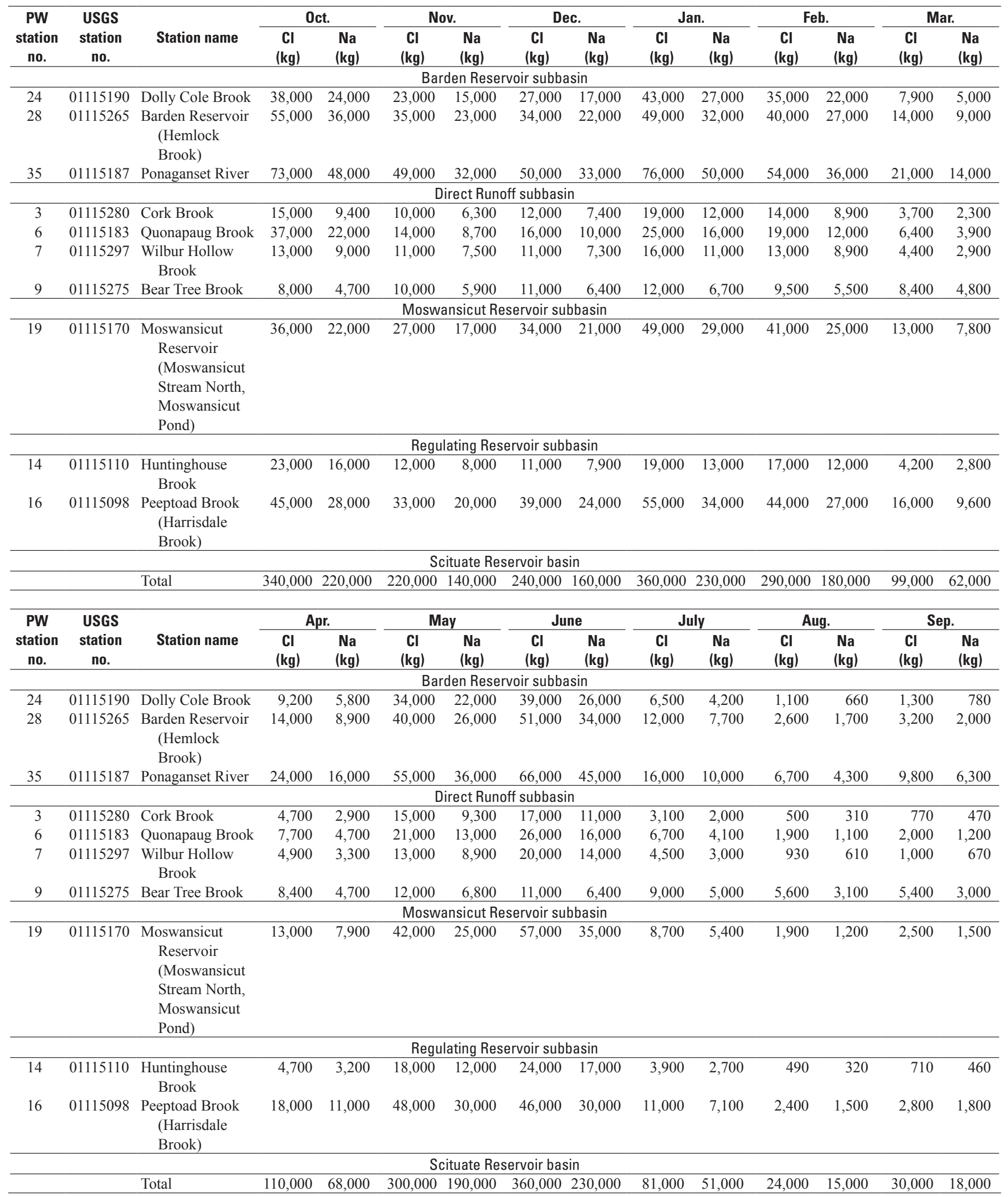




\section{Constituent Concentrations and Daily Loads and Yields}

Fecal indicator bacteria, chloride, and nutrients like phosphorus and nitrogen are commonly detected in natural water; at elevated concentrations, these constituents can render water unfit for the intended use. Fecal indicator bacteria, which are found in the intestines of warm-blooded animals, may indicate impairment from sewage contamination or from livestock or wildlife that defecate in or near the stream margin. Chloride originates in tributary streamwater from precipitation, weathering, or human activities like waste disposal and road deicing. Sources of nutrients in tributary streamwater include atmospheric deposition, leaching of naturally occurring organic material, discharge of groundwater that is enriched in nutrients from septic-system leachate, and runoff contaminated with fertilizer or animal waste. The ultimate intended use of water in the tributary streams is drinking water, which must meet specific water-quality standards. For this reason, Providence Water and the USGS closely monitor concentrations of these constituents in tributary streams. Median concentrations, loads, and yields of water-quality constituents are given in tables 7 and 8 .

\section{Bacteria}

Median concentrations of total coliform and $E$. coli bacteria were above the detection limit (3 CFU/100 mL) at nearly all sites (table 7). Total coliform bacteria concentrations were in most cases equal to or greater than $E$. coli concentrations (as expected because total coliform is more inclusive); the median concentrations among all sites in the drainage basin were equal to $43 \mathrm{CFU} / 100 \mathrm{~mL}$ for total coliform bacteria and $23 \mathrm{CFU} / 100 \mathrm{~mL}$ for $E$. coli bacteria. Median concentrations of total coliform and $E$. coli bacteria were greatest $(2,400 \mathrm{CFU} / 100 \mathrm{~mL}$ for both) at the Unnamed Tributary \#2 to Scituate Reservoir (Providence Water Station 2) (table 7). Concentrations of fecal indicator bacteria in some cases were lowest at monitoring stations immediately downstream from subbasin reservoirs, such as station 23 at the outlet of the Ponaganset Reservoir.

Median daily loads and yields of total coliform and E. coli bacteria varied over three orders of magnitude; the highest median daily yields were at station 6 (Quonapaug Brook) in the Direct Runoff subbasin (table 8). Although relatively high for monitoring stations in the Scituate Reservoir subbasin, median daily bacteria yields at this station are low compared to yields of indicator bacteria in sewage-contaminated streamwater or streamwater affected by stormwater runoff in an urban environment (Breault and others, 2002). The median daily loads of total coliform bacteria for the entire Scituate Reservoir drainage area ranged from 35 to $65,000 \mathrm{CFU} \times 10^{6} /$ day, and median daily yields ranged from 24 to $22,000 \mathrm{CFU} \times 10^{6} / \mathrm{day} / \mathrm{mi}^{2}$. The median daily loads for $E$. coli for the entire drainage area ranged from 18 to $13,000 \mathrm{CFU} \times 10^{6} /$ day, and median daily yields ranged from 34 to $4,500 \mathrm{CFU} \times 10^{6} / \mathrm{day} / \mathrm{mi}^{2}$ (table 8 ).

\section{Chloride}

The highest median chloride concentration $(74.9 \mathrm{mg} / \mathrm{L})$ was measured in the Direct Runoff subbasin at the Bear Tree Brook station (9) (table 7). Median daily chloride loads and yields varied among monitoring stations in the drainage area (table 8); the median chloride yield for the overall drainage area was about $81 \mathrm{~kg} / \mathrm{d} / \mathrm{mi}^{2}$. Ponaganset River (35) had the largest median daily chloride load $(1,100 \mathrm{~kg} / \mathrm{d})$, whereas the largest median daily chloride yield was determined for Bear Tree Brook (9) $\left(370 \mathrm{~kg} / \mathrm{d} / \mathrm{mi}^{2}\right)$; this yield is lower than the annual mean chloride yield $\left(180,000 \mathrm{~kg} / \mathrm{yr} / \mathrm{mi}^{2}\right.$ (table 5) or about $490 \mathrm{~kg} / \mathrm{d} / \mathrm{mi}^{2}$ ) measured at that station by using continuously measured specific-conductance records.

\section{Nutrients}

Median concentrations of nitrite and nitrate (table 7) were 0.001 and $0.02 \mathrm{mg} / \mathrm{L}$ as $\mathrm{N}$, respectively. Relatively high concentrations of nitrite and nitrate at some monitoring sites, such as Moswansicut Reservoir (22) in the Moswansicut Reservoir subbasin $(0.007 \mathrm{mg} / \mathrm{L}$ as $\mathrm{N}$ and $0.16 \mathrm{mg} / \mathrm{L}$, respectively), may have been affected by nitrogen-enriched runoff or groundwater (Nimiroski and others, 2008). The median concentration of orthophosphate for the entire study area (table 7) was $0.07 \mathrm{mg} / \mathrm{L}$ as $\mathrm{P}$. The maximum median concentration of orthophosphate $(0.39 \mathrm{mg} / \mathrm{L}$ as $\mathrm{P})$ was measured at Toad Pond (31). Nutrient loadings from the Ponaganset River (35) into the Scituate Reservoir - nitrite $(88 \mathrm{~g} / \mathrm{d})$, nitrate $(1,300 \mathrm{~g} / \mathrm{d})$, and orthophosphate $(1,600 \mathrm{~g} / \mathrm{d})$ were among the largest of all the sampled stations. Median daily orthophosphate loads for WY 2006 were larger at only two stations, Wilbur Hollow Brook (7; 2,000 g/d) and Regulating Reservoir $(15 ; 2,300 \mathrm{~g} / \mathrm{d})$. The largest median daily nutrient yield for nitrite $\left(26 \mathrm{~g} / \mathrm{d} / \mathrm{mi}^{2}\right)$ was determined at Unnamed Tributary to Westconnaug Reservoir (11), for nitrate $\left(770 \mathrm{~g} / \mathrm{d} / \mathrm{mi}^{2}\right)$ at Bear Tree Brook (9), and for orthophosphate $\left(690 \mathrm{~g} / \mathrm{d} / \mathrm{mi}^{2}\right)$ at Quonapaug Brook (6) (table 8). 
Table 7. Median values for water-quality data collected at Providence Water stations, by tributary reservoir subbasin, in the Scituate Reservoir drainage area, Rhode Island, October 1, 2005, through September 30, 2006.

[Water-quality data are from samples collected and analyzed by Providence Water (PW); USGS, U.S. Geological Survey; no., number; PCU, platinum cobalt units; NTU, nephelometric turbidity units; CFU/100 mL, colony forming units per 100 milliliters; E. coli., Escherichia coli; mg/L, milligrams per liter; CaCO , calcium carbonate; $\mathrm{N}$, nitrate; $\mathrm{P}$, phosphorus; --, no data; $<$, less than]

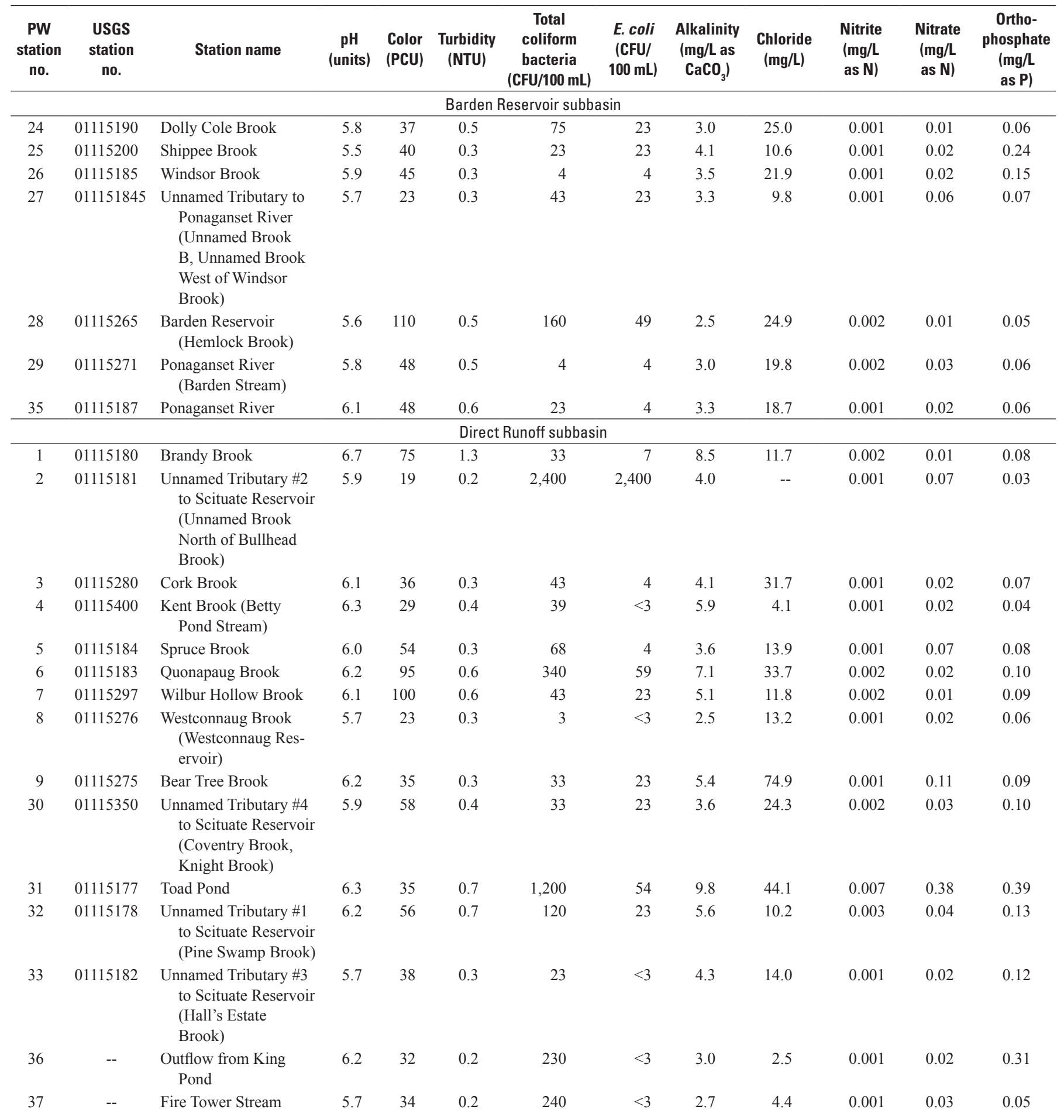


Table 7. Median values for water-quality data collected at Providence Water stations, by tributary reservoir subbasin, in the Scituate Reservoir drainage area, Rhode Island, October 1, 2005, through September 30, 2006. - Continued

[Water-quality data are from samples collected and analyzed by Providence Water (PW); USGS, U.S. Geological Survey; no., number; PCU, platinum cobalt units; NTU, nephelometric turbidity units; CFU/100 mL, colony forming units per 100 milliliters; E. coli., Escherichia coli; mg/L, milligrams per liter; CaCO , calcium carbonate; N, nitrate; P, phosphorus; --, no data; <, less than]

\begin{tabular}{|c|c|c|c|c|c|c|c|c|c|c|c|c|}
\hline $\begin{array}{c}\text { PW } \\
\text { station } \\
\text { no. }\end{array}$ & $\begin{array}{l}\text { USGS } \\
\text { station } \\
\text { no. }\end{array}$ & Station name & $\begin{array}{c}\mathrm{pH} \\
\text { (units) }\end{array}$ & $\begin{array}{l}\text { Color } \\
\text { (PCU) }\end{array}$ & $\begin{array}{c}\text { Turbidity } \\
\text { (NTU) }\end{array}$ & $\begin{array}{c}\text { Total } \\
\text { coliform } \\
\text { bacteria } \\
\text { (CFU/100 mL) }\end{array}$ & $\begin{array}{l}\text { E. coli } \\
\text { (CFU/ } \\
100 \mathrm{~mL} \text { ) }\end{array}$ & $\begin{array}{l}\text { Alkalinity } \\
\text { (mg/L as } \\
\mathrm{CaCO}_{3} \text { ) }\end{array}$ & $\begin{array}{c}\text { Chloride } \\
\text { (mg/L) }\end{array}$ & $\begin{array}{l}\text { Nitrite } \\
\text { (mg/L } \\
\text { as } N \text { ) }\end{array}$ & $\begin{array}{l}\text { Nitrate } \\
\text { (mg/L } \\
\text { as N) }\end{array}$ & $\begin{array}{c}\text { Ortho- } \\
\text { phosphate } \\
\text { (mg/L } \\
\text { as P) }\end{array}$ \\
\hline 19 & 01115170 & $\begin{array}{l}\text { Moswansicut Reservoir } \\
\text { (Moswansicut } \\
\text { Stream North, Mo- } \\
\text { swansicut Pond) }\end{array}$ & 6.7 & 31 & 0.9 & 33 & 12 & 8.5 & 41.1 & 0.002 & 0.03 & 0.04 \\
\hline 21 & 01115165 & $\begin{array}{c}\text { Unnamed Tributary \#2 } \\
\text { to Moswansicut Res- } \\
\text { ervoir (Brook from } \\
\text { Kimball Reservoir) }\end{array}$ & 6.3 & 90 & 0.6 & 43 & 23 & 10 & 40.0 & 0.002 & 0.07 & 0.05 \\
\hline 34 & 01115164 & Kimball Stream & 6.3 & 79 & 0.8 & 43 & 43 & 9.8 & 31.9 & 0.002 & $<0.01$ & 0.16 \\
\hline \multicolumn{13}{|c|}{ Ponaganset Reservoir subbasin } \\
\hline 23 & 011151843 & Ponaganset Reservoir & 5.5 & 17 & 0.4 & 14 & $<3$ & 2.2 & 11.5 & 0.001 & 0.02 & 0.04 \\
\hline \multicolumn{13}{|c|}{ Regulating Reservoir subbasin } \\
\hline 13 & 01115176 & Regulating Reservoir & 6.5 & 34 & 0.6 & 4 & 4 & 7.6 & 33.0 & 0.001 & 0.01 & 0.07 \\
\hline 14 & 01115110 & Huntinghouse Brook & 6.3 & 30 & 0.4 & 240 & 43 & 5.8 & 10.5 & 0.001 & 0.01 & 0.12 \\
\hline 15 & 01115115 & $\begin{array}{l}\text { Regulating Reservoir } \\
\text { (Rush Brook) }\end{array}$ & 6.5 & 41 & 0.6 & 240 & 23 & 7.1 & 49.1 & 0.001 & 0.02 & 0.10 \\
\hline 16 & 01115098 & $\begin{array}{l}\text { Peeptoad Brook } \\
\text { (Harrisdale Brook) }\end{array}$ & 6.4 & 34 & 0.8 & 75 & 9 & 8.0 & 30.7 & 0.001 & 0.01 & 0.07 \\
\hline 17 & 01115119 & $\begin{array}{l}\text { Dexter Pond (Paine } \\
\text { Pond) }\end{array}$ & 5.7 & 95 & 0.4 & 23 & 23 & 4.9 & 34.8 & 0.001 & $<0.01$ & 0.15 \\
\hline 12 & 011152745 & $\begin{array}{l}\text { Unnamed Tributary to } \\
\text { Westconnaug Brook } \\
\text { (Unnamed Brook } \\
\text { north of Westcon- } \\
\text { naug Reservoir) }\end{array}$ & 5.7 & 81 & 1.1 & 23 & 23 & 4.8 & 44.0 & 0.002 & $<0.01$ & 0.04 \\
\hline \multicolumn{13}{|c|}{ Scituate Reservoir basin } \\
\hline & & Median & 6.1 & 40 & 0.4 & 43 & 23 & 4.6 & 24.6 & 0.001 & 0.02 & 0.07 \\
\hline
\end{tabular}




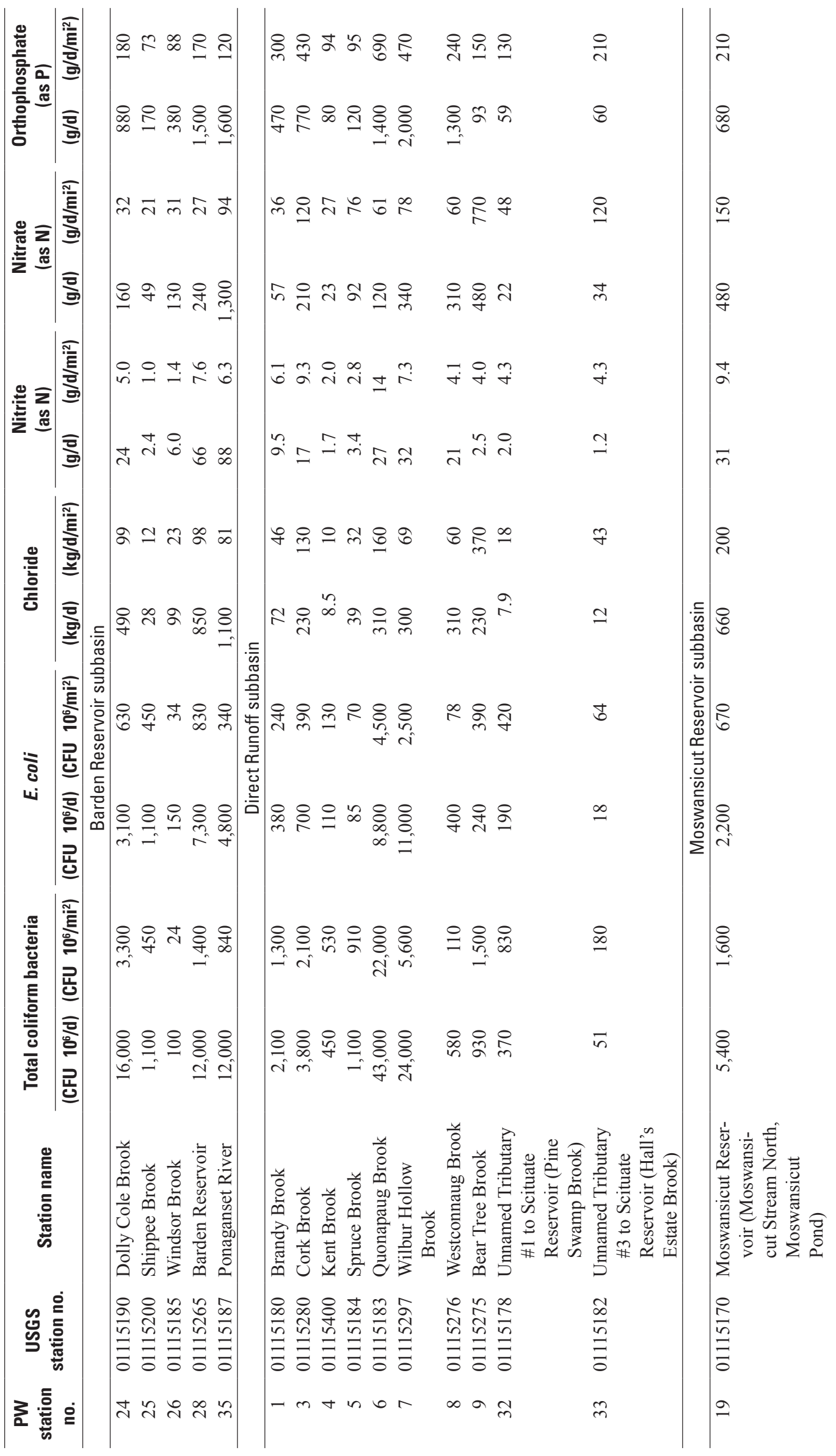




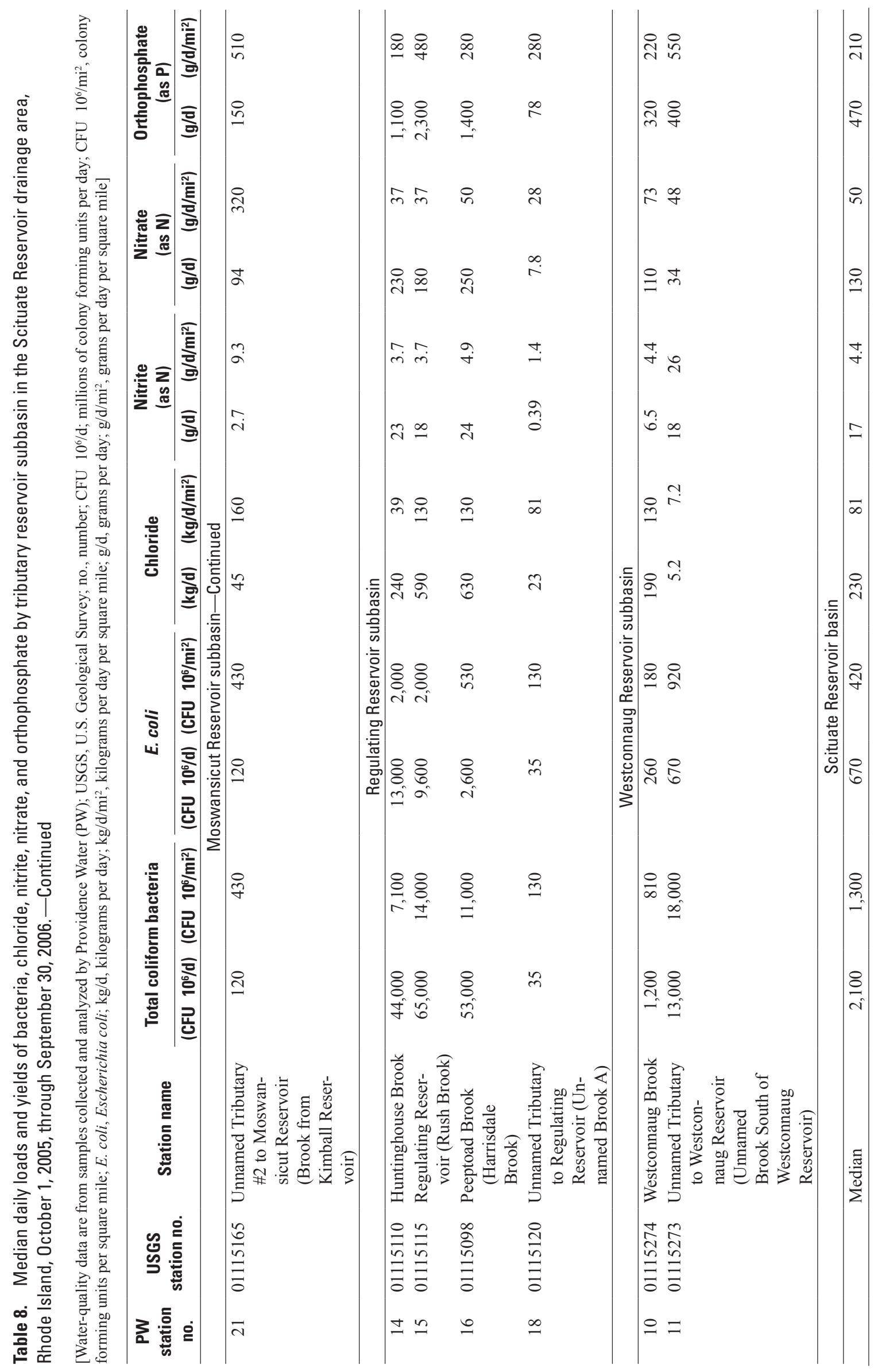




\section{References Cited}

Breault, R.F., Sorenson, J.R., and Weiskel, P.K., 2002, Streamflow, water quality, and contaminant loads in the lower Charles River watershed, Massachusetts, 1999-2000: U.S. Geological Survey Water-Resources Investigations Report 02-4137, $131 \mathrm{p}$.

Breault, R.F., Waldron, M.C., Barlow, L.K., and Dickerman, D.C., 2000, Water-quality conditions in relation to drainage basin characteristics in the Scituate Reservoir basin, Rhode Island, 1982-95: U.S. Geological Survey Water-Resources Investigations Report 00-4086, 46 p.

Granato, G.E., 2008, Computer programs for obtaining and analyzing daily mean streamflow data from the U.S. Geological Survey National Water Information System Web Site: U.S. Geological Survey Open-File Report 2008-1362, CD-ROM.

Helsel, D.R., and Hirsch, R.M., 1992, Statistical methods in water resources: New York, Elsevier, Studies in Environmental Science 49, $522 \mathrm{p}$.

Hirsch, R.M., 1982, A comparison of four streamflow record extension techniques: Water Resources Research, v. 18, no. 4, p. 1081-1088.

Hirsch, R.M., and Gilroy, E.J., 1984, Methods of fitting a straight line to data-Examples in water resources: Water Resources Bulletin, v. 20, no. 5, p. 705-711.

National Institute of Standards and Technology/SEmiconductor MAnufacturing TECHnology, 2003, NIST/SEMATECH e-Handbook of Statistical Methods, accessed April 15, 2008, at http://www.itl.nist.gov/div898/handbook/.
Nimiroski, M.T., DeSimone, L.A., and Waldron, M.C., 2008, Water-quality conditions and constituent loads, 1996-2002, and water-quality trends, 1983-2002, in the Scituate Reservoir drainage area, Rhode Island: U.S. Geological Survey Scientific Investigations Report 2008-5060, 55 p.

Nimiroski, M.T., and Waldron, M.C., 2002, Sources of sodium and chloride in the Scituate Reservoir drainage basin, Rhode Island: U.S. Geological Survey Water-Resources Investigations Report 02-4149, $16 \mathrm{p}$.

Providence Water Supply Board Water Quality Laboratory, 2003, Quality Assurance Program Manual: Providence Water Supply Board, variously paged.

Ries, K.G., III, and Friesz, P.J., 2000, Methods for estimating low-flow statistics for Massachusetts streams: U.S. Geological Survey Water-Resources Investigations Report 00-4136, $81 \mathrm{p}$.

Tasker, G.D., and Driver, N.E., 1988, Nationwide regression models for predicting urban runoff water quality at unmonitored sites: Water Resources Bulletin, v. 24, no. 5, p. 1090-1101.

U.S. Geological Survey, 2006, National Water Information System, accessed November 17, 2008, at http://waterdata. usgs.gov/nwis.

U.S. Geological Survey, 2007, Water-resources data for the United States, Water Year 2006: U.S. Geological Survey Water-Data Report WDR-US-2006, accessed November 5, 2009, at http://wdr.water.usgs.gov/.

Wagner, R.J., Boulger, R.W., Jr., Oblinger, C.J., and Smith, B.A., 2006, Guidelines and standard procedures for continuous water-quality monitors - Station operation, record computation, and data reporting: U.S. Geological Survey Techniques and Methods 1-D3, 51 p., 8 attachments, accessed April 10, 2006, at http://pubs.water.usgs.gov/tm1d3. 
Table 3. Daily loads of bacteria, chloride, nitrite, nitrate, and orthophosphate by tributary reservoir subbasin in the Scituate Reservoir drainage area, Rhode Island, October 1, 2005, through September 30, 2006.

[Water-quality data are from samples collected and analyzed by Providence Water (PW); USGS, U.S. Geological Survey; no., number; ftºs, cubic feet per second; $\mathrm{CFU} \times 10^{6} / \mathrm{d}$; millions of colony forming units per day; E. coli, Escherichia coli; kg/d, kilograms per day; g/d, grams per day; --, no data]

\begin{tabular}{|c|c|c|c|c|c|c|c|c|c|c|}
\hline $\begin{array}{c}\text { PW } \\
\text { station } \\
\text { no. }\end{array}$ & $\begin{array}{c}\text { USGS } \\
\text { station } \\
\text { no. }\end{array}$ & Station name & Date & $\begin{array}{l}\text { Daily mean } \\
\text { streamflow } \\
\left(\mathrm{ft}^{3} / \mathrm{s}\right)\end{array}$ & $\begin{array}{c}\text { Total } \\
\text { coliform } \\
\text { bacteria } \\
\left.\text { (CFU } \times 10^{6} / d\right)\end{array}$ & $\begin{array}{c}\text { E. coli } \\
\left(\mathrm{CFU} \times 10^{6} / \mathrm{d}\right)\end{array}$ & $\begin{array}{c}\text { Chloride } \\
\text { (kg/d) }\end{array}$ & $\begin{array}{c}\text { Nitrite } \\
\text { (g/d as } N)\end{array}$ & $\begin{array}{l}\text { Nitrate } \\
(\mathbf{g} / \mathbf{d} \text { as } N)\end{array}$ & $\begin{array}{c}\text { Ortho- } \\
\text { phosphate } \\
\text { (g/d as P) }\end{array}$ \\
\hline \multirow[t]{7}{*}{24} & 01115190 & Dolly Cole Brook & $11 / 4 / 2005$ & 8.9 & 16,000 & 5,000 & 500 & 22 & 220 & 3,700 \\
\hline & & & $12 / 2 / 2005$ & 24 & 140,000 & 14,000 & 1,400 & 59 & 1,200 & 12,000 \\
\hline & & & $3 / 3 / 2006$ & 5.2 & 31,000 & 190 & 370 & 13 & 130 & 890 \\
\hline & & & $4 / 7 / 2006$ & 5.6 & 5,900 & 210 & 430 & 14 & 140 & 550 \\
\hline & & & $5 / 5 / 2006$ & 13 & 1,300 & 1,300 & 910 & 32 & 160 & 950 \\
\hline & & & $6 / 2 / 2006$ & 5.0 & 56,000 & 5,300 & 270 & 24 & 240 & 610 \\
\hline & & & 7/7/2006 & 8.9 & 33,000 & 9,400 & 490 & 44 & 110 & 870 \\
\hline \multirow{3}{*}{25} & & & $1 / 1 / 2006$ & 14 & 7,900 & 7,900 & 390 & 34 & 340 & 8,200 \\
\hline & & & $4 / 21 / 2006$ & 1.0 & 1,100 & 1,100 & 31 & 2.4 & 49 & 170 \\
\hline & & & $7 / 21 / 2006$ & 1.1 & -- & -- & 26 & -- & -- & -- \\
\hline \multirow[t]{4}{*}{26} & 01115185 & Windsor Brook & $10 / 1 / 2005$ & 0.02 & 13 & 13 & 1.2 & 0.06 & 0.28 & 9.6 \\
\hline & & & $1 / 1 / 2006$ & 16 & 1,600 & 1,600 & 640 & 39 & 1,600 & 6,300 \\
\hline & & & $4 / 21 / 2006$ & 1.5 & 150 & 150 & 84 & 3.7 & 18 & 220 \\
\hline & & & $7 / 21 / 2006$ & 1.7 & 62 & -- & 110 & 8.3 & 250 & 540 \\
\hline \multirow[t]{6}{*}{28} & 01115265 & Barden Reservoir & $10 / 1 / 2005$ & 0.16 & 9,400 & 9,400 & 12 & 1.2 & 16 & 47 \\
\hline & & & $11 / 8 / 2005$ & 15 & 28,000 & 28,000 & 930 & 73 & 180 & 11,000 \\
\hline & & & $12 / 13 / 2005$ & 15 & 8,400 & 3,300 & 900 & 110 & 180 & 4,000 \\
\hline & & & $7 / 11 / 2006$ & 8.1 & 480,000 & 480,000 & 460 & 40 & 99 & 99 \\
\hline & & & 8/8/2006 & 0.87 & 5,100 & 5,100 & 69 & 6.4 & 11 & 300 \\
\hline & & & $9 / 12 / 2006$ & 0.90 & 5,300 & 5,300 & 62 & 6.6 & 11 & 22 \\
\hline \multirow[t]{11}{*}{35} & 01115187 & Ponaganset River & $11 / 4 / 2005$ & 27 & 160,000 & 28,000 & 27 & 66 & 1,300 & 5,900 \\
\hline & & & $12 / 2 / 2005$ & 59 & 33,000 & 5,800 & 59 & 140 & 1,400 & 16,000 \\
\hline & & & $1 / 1 / 2006$ & 49 & 18,000 & 4,800 & 49 & 120 & 3,600 & 56,000 \\
\hline & & & $2 / 3 / 2006$ & 101 & 9,900 & 9,900 & 101 & 740 & 2,500 & 25,000 \\
\hline & & & $3 / 3 / 2006$ & 21 & 12,000 & 770 & 21 & 51 & 1,500 & 3,100 \\
\hline & & & $4 / 7 / 2006$ & 22 & 4,800 & 810 & 22 & 54 & 1,100 & 540 \\
\hline & & & $5 / 5 / 2006$ & 36 & 1,300 & 1,300 & 36 & 88 & 440 & 880 \\
\hline & & & $6 / 2 / 2006$ & 22 & $1,300,000$ & $1,300,000$ & 22 & 110 & 2,200 & 1,100 \\
\hline & & & 7/7/2006 & 22 & 40,000 & 23,000 & 22 & 110 & 270 & 1,600 \\
\hline & & & $8 / 4 / 2006$ & 7.0 & 3,900 & 3,900 & 7.0 & 34 & 340 & 510 \\
\hline & & & $9 / 1 / 2006$ & 7.5 & 1,700 & 1,700 & 7.5 & 18 & 730 & 1,500 \\
\hline
\end{tabular}


Table 3. Daily loads of bacteria, chloride, nitrite, nitrate, and orthophosphate by tributary reservoir subbasin in the Scituate Reservoir drainage area, Rhode Island, October 1, 2005, through September 30, 2006. - Continued

[Water-quality data are from samples collected and analyzed by Providence Water (PW); USGS, U.S. Geological Survey; no., number; ftºs, cubic feet per second; $\mathrm{CFU} \times 10^{6} / \mathrm{d}$; millions of colony forming units per day; E. coli, Escherichia coli; $\mathrm{kg} / \mathrm{d}$, kilograms per day; g/d, grams per day; --, no data]

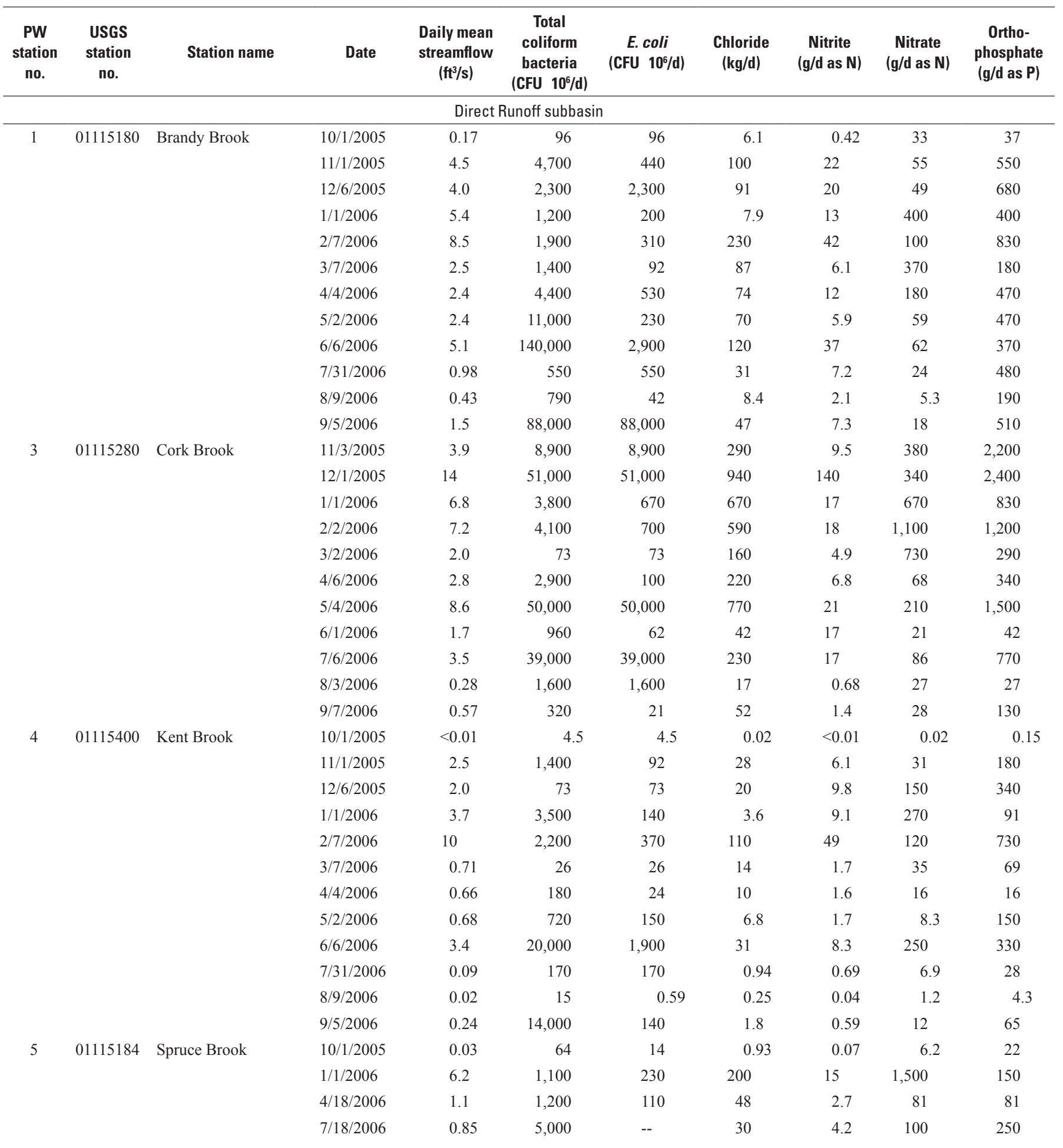


Table 3. Daily loads of bacteria, chloride, nitrite, nitrate, and orthophosphate by tributary reservoir subbasin in the Scituate Reservoir drainage area, Rhode Island, October 1, 2005, through September 30, 2006. - Continued

[Water-quality data are from samples collected and analyzed by Providence Water (PW); USGS, U.S. Geological Survey; no., number; ftºs, cubic feet per second; $\mathrm{CFU} \times 10^{6} / \mathrm{d}$; millions of colony forming units per day; E. coli, Escherichia coli; $\mathrm{kg} / \mathrm{d}$, kilograms per day; g/d, grams per day; --, no data]

\begin{tabular}{|c|c|c|c|c|c|c|c|c|c|c|}
\hline $\begin{array}{l}\text { PW } \\
\text { station } \\
\text { no. }\end{array}$ & $\begin{array}{c}\text { USGS } \\
\text { station } \\
\text { no. }\end{array}$ & Station name & Date & $\begin{array}{l}\text { Daily mean } \\
\text { streamflow } \\
\qquad\left(\mathrm{ft}^{3} / \mathrm{s}\right)\end{array}$ & $\begin{array}{c}\text { Total } \\
\text { coliform } \\
\text { bacteria } \\
\left(\mathrm{CFU} \times 10^{6} / \mathrm{d}\right)\end{array}$ & $\begin{array}{c}\text { E. coli } \\
\left(\text { CFU } \times 10^{6} / d\right)\end{array}$ & $\begin{array}{c}\text { Chloride } \\
\text { (kg/d) }\end{array}$ & $\begin{array}{c}\text { Nitrite } \\
\text { (g/d as } N)\end{array}$ & $\begin{array}{c}\text { Nitrate } \\
\text { (g/d as } N)\end{array}$ & $\begin{array}{c}\text { Ortho- } \\
\text { phosphate } \\
\text { (g/d as } P \text { ) }\end{array}$ \\
\hline \multirow[t]{7}{*}{6} & \multirow[t]{7}{*}{01115183} & \multirow[t]{7}{*}{ Quonapaug Brook } & $11 / 1 / 2005$ & 6.7 & 75,000 & 7,000 & 470 & 33 & 82 & 1,600 \\
\hline & & & $12 / 6 / 2005$ & 5.8 & 11,000 & 11,000 & 380 & 57 & 430 & 4,000 \\
\hline & & & $3 / 7 / 2006$ & 2.9 & 3,100 & 110 & 240 & 7.1 & 710 & 280 \\
\hline & & & $4 / 4 / 2006$ & 2.8 & 75,000 & 1,600 & 240 & 14 & 140 & 480 \\
\hline & & & $5 / 2 / 2006$ & 2.8 & 75,000 & 75,000 & 240 & 14 & 34 & 270 \\
\hline & & & $6 / 6 / 2006$ & 8.2 & 42,000 & 42,000 & 590 & 60 & 100 & 1,600 \\
\hline & & & $7 / 31 / 2006$ & 0.75 & 44,000 & 44,000 & 78 & 9.2 & 18 & 400 \\
\hline \multirow{10}{*}{7} & \multirow{10}{*}{01115297} & \multirow{10}{*}{ Wilbur Hollow Brook } & $12 / 1 / 2005$ & 35 & 210,000 & 210,000 & 720 & 600 & 860 & 6,000 \\
\hline & & & $1 / 1 / 2006$ & 18 & 480,000 & 19,000 & 520 & 44 & 440 & 4,000 \\
\hline & & & $2 / 2 / 2006$ & 19 & 11,000 & 11,000 & 530 & 93 & 230 & 4,600 \\
\hline & & & $3 / 2 / 2006$ & 6.0 & 1,300 & 220 & 200 & 15 & 590 & 590 \\
\hline & & & $4 / 6 / 2006$ & 7.9 & 1,700 & 290 & 280 & 19 & 580 & 970 \\
\hline & & & $5 / 4 / 2006$ & 23 & 24,000 & 24,000 & 500 & 110 & 560 & 4,500 \\
\hline & & & $6 / 1 / 2006$ & 5.0 & 290,000 & 2,800 & 420 & 12 & 490 & 1,100 \\
\hline & & & $7 / 6 / 2006$ & 9.8 & 58,000 & 58,000 & 270 & 96 & 120 & 35,000 \\
\hline & & & $8 / 3 / 2006$ & 0.96 & 540 & 540 & 24 & 9.4 & 23 & 160 \\
\hline & & & 9/7/2006 & 1.8 & 180 & 66 & 54 & 18 & 22 & 310 \\
\hline \multirow{4}{*}{8} & \multirow{4}{*}{01115276} & \multirow{4}{*}{ Westconnaug Brook } & $4 / 24 / 2006$ & 10 & 370 & 370 & 370 & 24 & 240 & 2,900 \\
\hline & & & $5 / 12 / 2006$ & 8.9 & 330 & 330 & 280 & 22 & 440 & 1,300 \\
\hline & & & $6 / 9 / 2006$ & 15 & 88,000 & 88,000 & 420 & 37 & 370 & 730 \\
\hline & & & $7 / 14 / 2006$ & 7.3 & 4,100 & 4,100 & 210 & 18 & 360 & 360 \\
\hline \multirow[t]{4}{*}{9} & \multirow[t]{4}{*}{01115275} & \multirow[t]{4}{*}{ Bear Tree Brook } & $10 / 1 / 2005$ & 0.23 & 240 & 240 & 33 & 0.56 & 17 & 79 \\
\hline & & & $1 / 1 / 2006$ & 2.2 & 1,200 & 1,200 & 360 & 5.4 & 810 & 54 \\
\hline & & & $4 / 18 / 2006$ & 1.1 & 620 & 40 & 220 & 2.7 & 160 & 110 \\
\hline & & & $7 / 18 / 2006$ & 0.95 & 56,000 & -- & 230 & 2.3 & 790 & 440 \\
\hline \multirow[t]{4}{*}{32} & \multirow[t]{4}{*}{01115178} & \multirow{4}{*}{$\begin{array}{l}\text { Unnamed Tributary } \\
\text { \#1 to Scituate } \\
\text { Reservoir (Pine } \\
\text { Swamp Brook) }\end{array}$} & $10 / 1 / 2005$ & 0.03 & 190 & 190 & 1.2 & 0.08 & 1.7 & 12 \\
\hline & & & $1 / 1 / 2006$ & 1.0 & 560 & 560 & 18 & 24 & 240 & 1,700 \\
\hline & & & $4 / 20 / 2006$ & 0.32 & 12 & 12 & 7.7 & 1.6 & 39 & 86 \\
\hline & & & $7 / 20 / 2006$ & 0.32 & 8,600 & -- & 8.2 & 2.3 & 3.9 & 31 \\
\hline
\end{tabular}


Table 3. Daily loads of bacteria, chloride, nitrite, nitrate, and orthophosphate by tributary reservoir subbasin in the Scituate Reservoir drainage area, Rhode Island, October 1, 2005, through September 30, 2006. —Continued

[Water-quality data are from samples collected and analyzed by Providence Water (PW); USGS, U.S. Geological Survey; no., number; ftºs, cubic feet per second; CFU $\times 10^{6} / \mathrm{d}$; millions of colony forming units per day; E. coli, Escherichia coli; kg/d, kilograms per day; g/d, grams per day; --, no data]

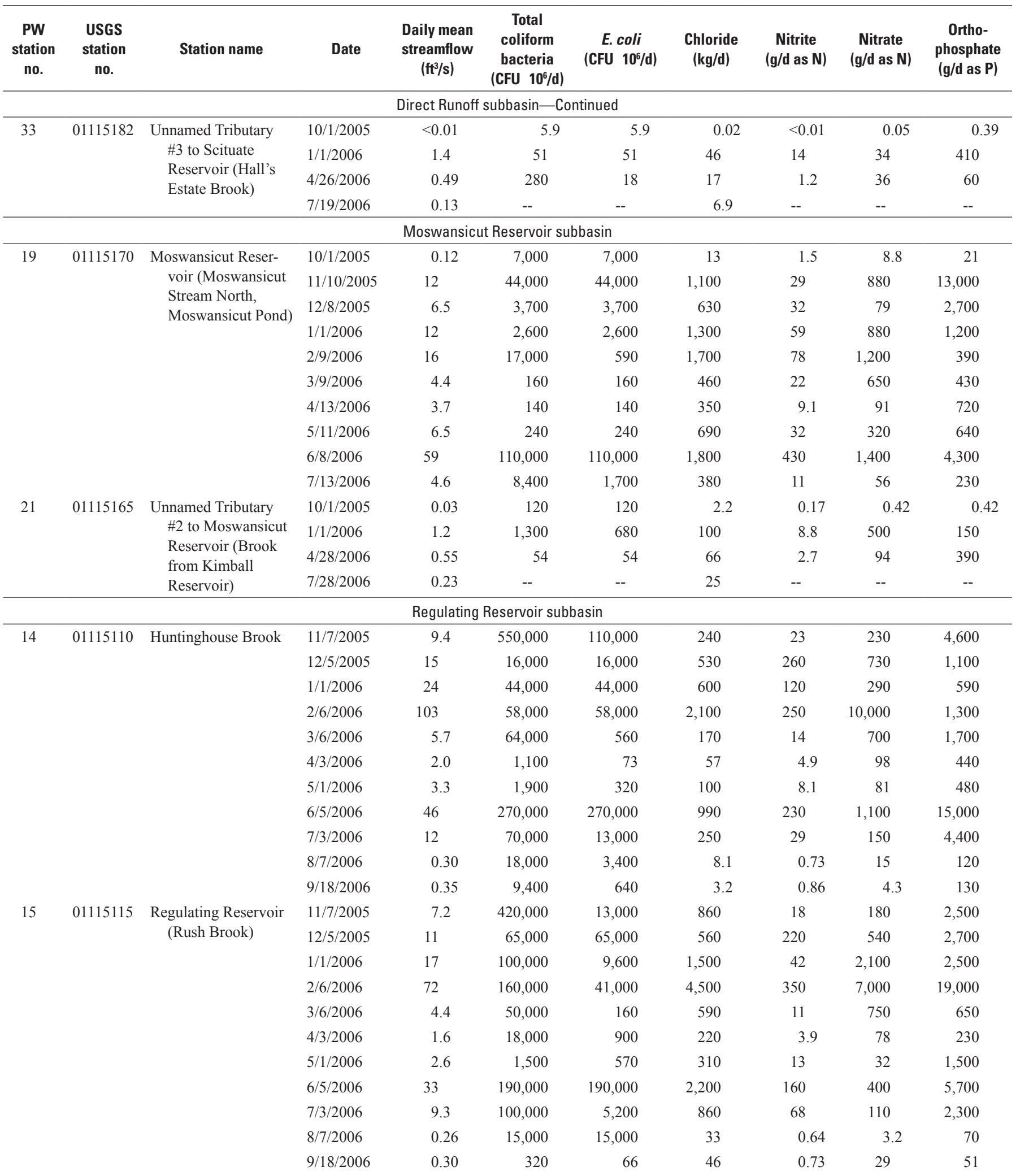


Table 3. Daily loads of bacteria, chloride, nitrite, nitrate, and orthophosphate by tributary reservoir subbasin in the Scituate Reservoir drainage area, Rhode Island, October 1, 2005, through September 30, 2006. - Continued

[Water-quality data are from samples collected and analyzed by Providence Water (PW); USGS, U.S. Geological Survey; no., number; ftºs, cubic feet per second; $\mathrm{CFU} \times 10^{6} / \mathrm{d}$; millions of colony forming units per day; E. coli, Escherichia coli; $\mathrm{kg} / \mathrm{d}$, kilograms per day; g/d, grams per day; --, no data]

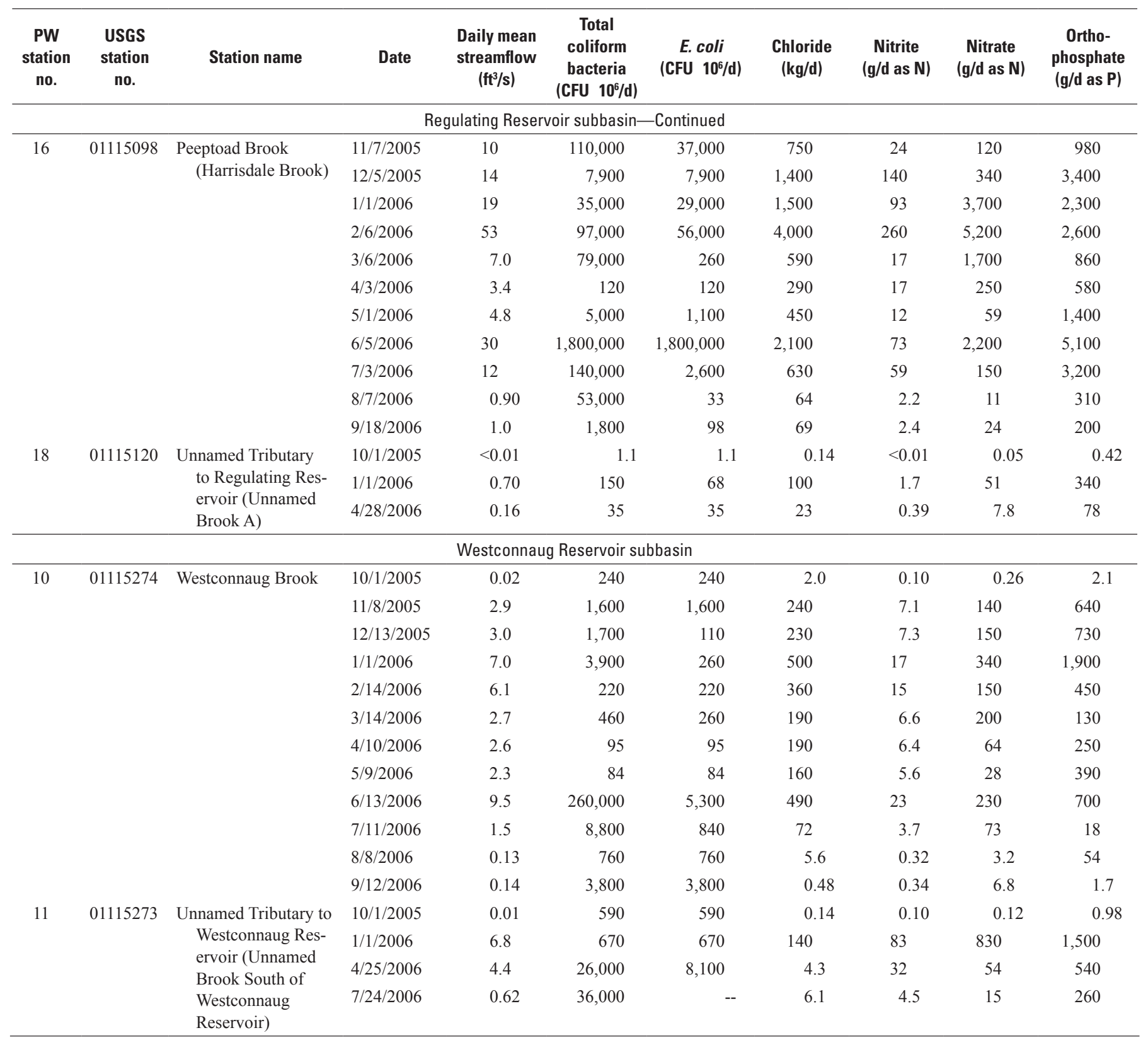


Prepared by the Pembroke and Denver Publishing Service Centers.

For more information concerning this report, contact:

\author{
Office of the Deputy Director \\ U.S. Geological Survey \\ Rhode Island Subdistrict Office \\ 42 Albion Road, Suite 107 \\ Lincoln, RI 02865 \\ rbreault@usgs.gov \\ or visit our Web site at: \\ http://ri.water.usgs.gov
}


4. $70 x^{2}$ sinter.t. 7. 25 b. 100 , 3. o. 1029

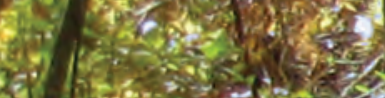

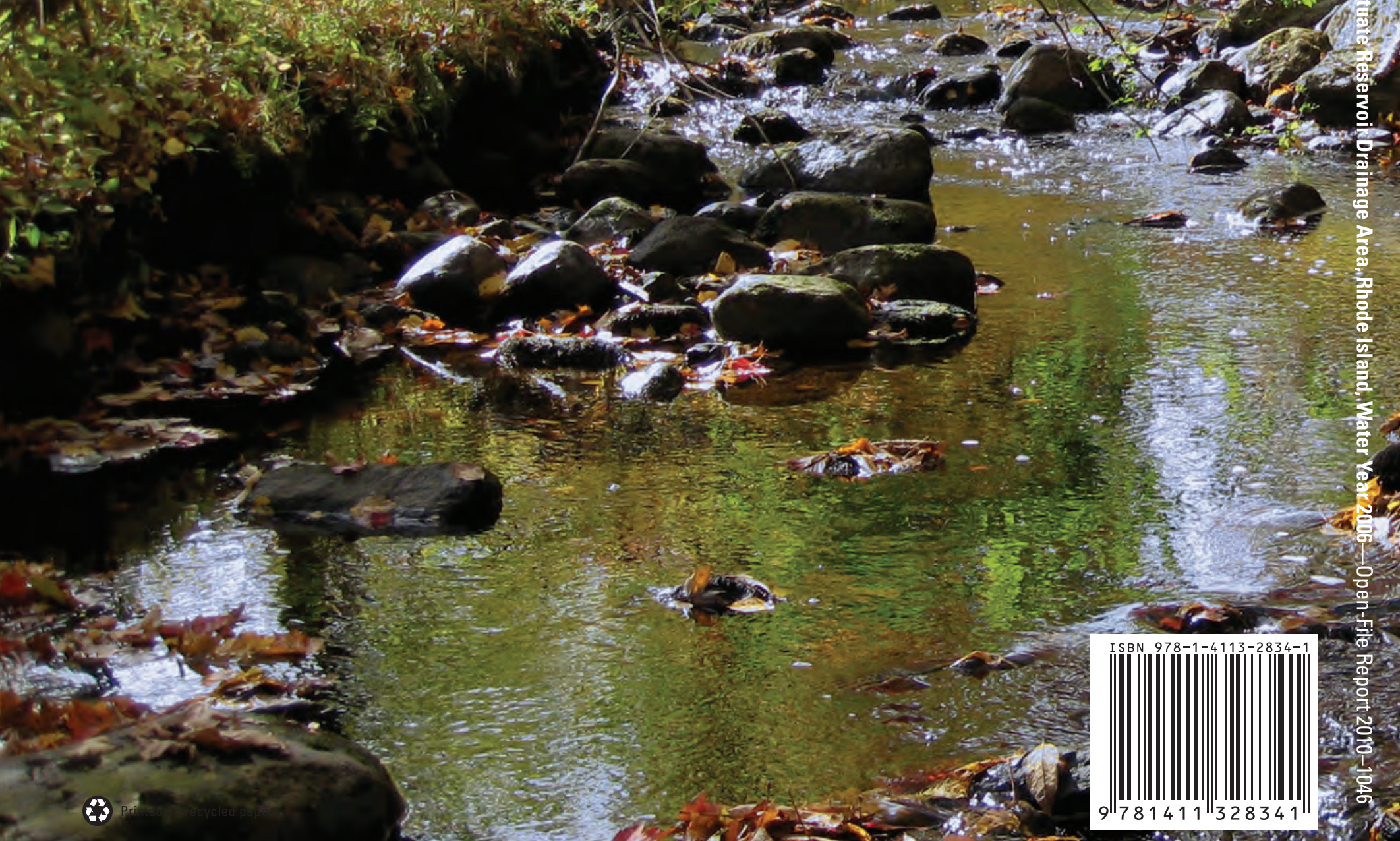

